In cooperation with the West Virginia Bureau for Public Health Office of Environmental Health Services

\title{
Geohydrology and Simulation of Ground-Water Flow in Ohio River Alluvial Aquifers near Point Pleasant, Lubeck, Parkersburg, Vienna, Moundsville, and Glendale, West Virginia
}

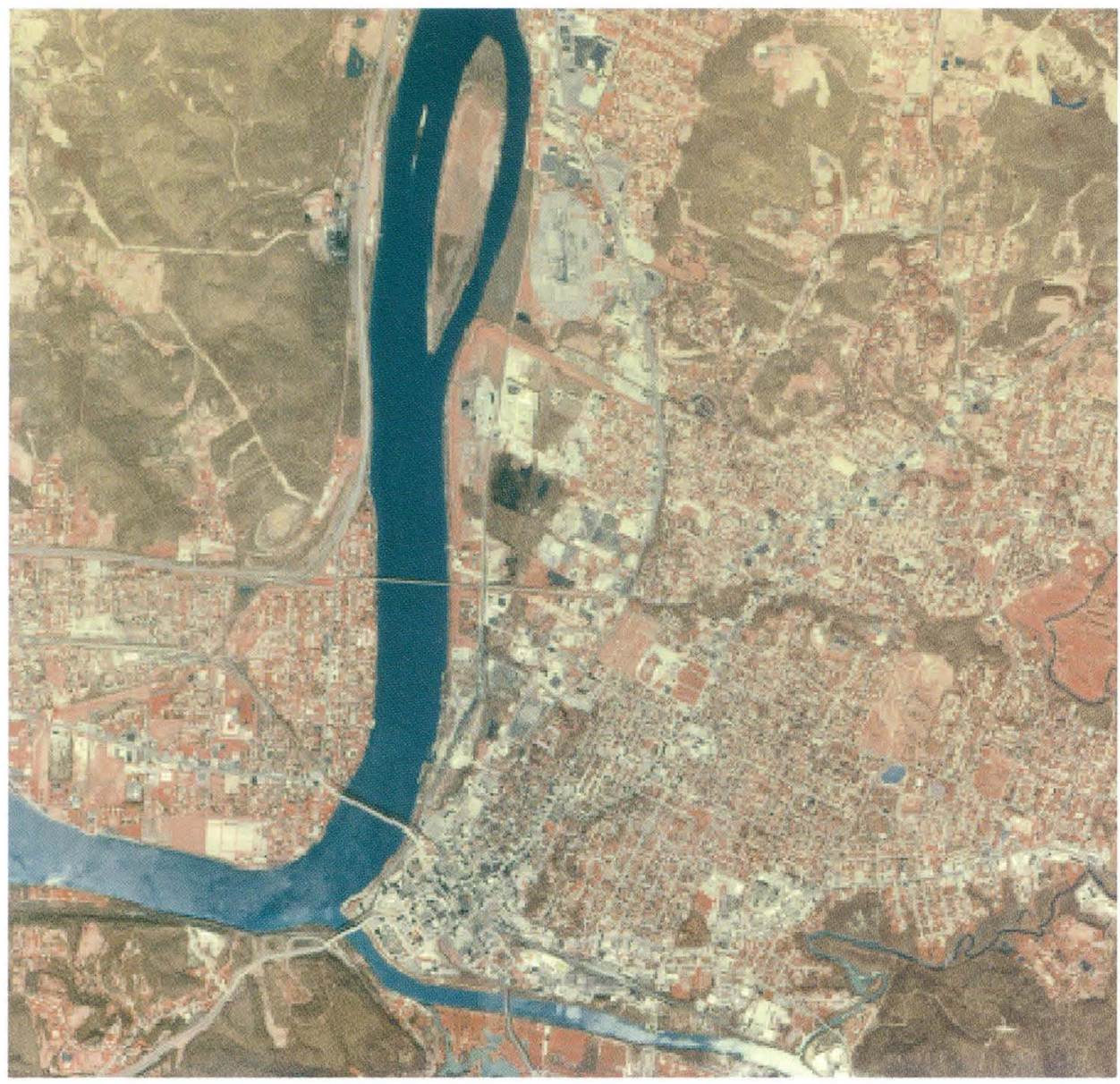

Scientific Investigations Report 2004-5088 
Front cover image: U.S. Geological Survey digital orthophoto quarter quadrangles (1996) showing the Ohio River and Parkersburg, West Virginia. 


\section{Geohydrology and Simulation of Ground-Water Flow in Ohio River Alluvial Aquifers near Point Pleasant, Lubeck, Parkersburg, Vienna, Moundsville, and Glendale, West Virginia}

By Mark D. Kozar and Kurt J. McCoy 


\title{
U.S. Department of the Interior Gale A. Norton, Secretary
}

\author{
U.S. Geological Survey \\ Charles G. Groat, Director
}

U.S. Geological Survey, Reston, Virginia: 2004

For sale by U.S. Geological Survey, Information Services

Box 25286, Denver Federal Center

Denver, C0 80225

For more information about the USGS and its products:

Telephone: 1-888-ASK-USGS

World Wide Web: http://www.usgs.gov/

Any use of trade, product, or firm names in this publication is for descriptive purposes only and does not imply endorsement by the U.S. Government.

Although this report is in the public domain, permission must be secured from the individual copyright owners to reproduce any copyrighted materials contained within this report. 


\section{Contents}

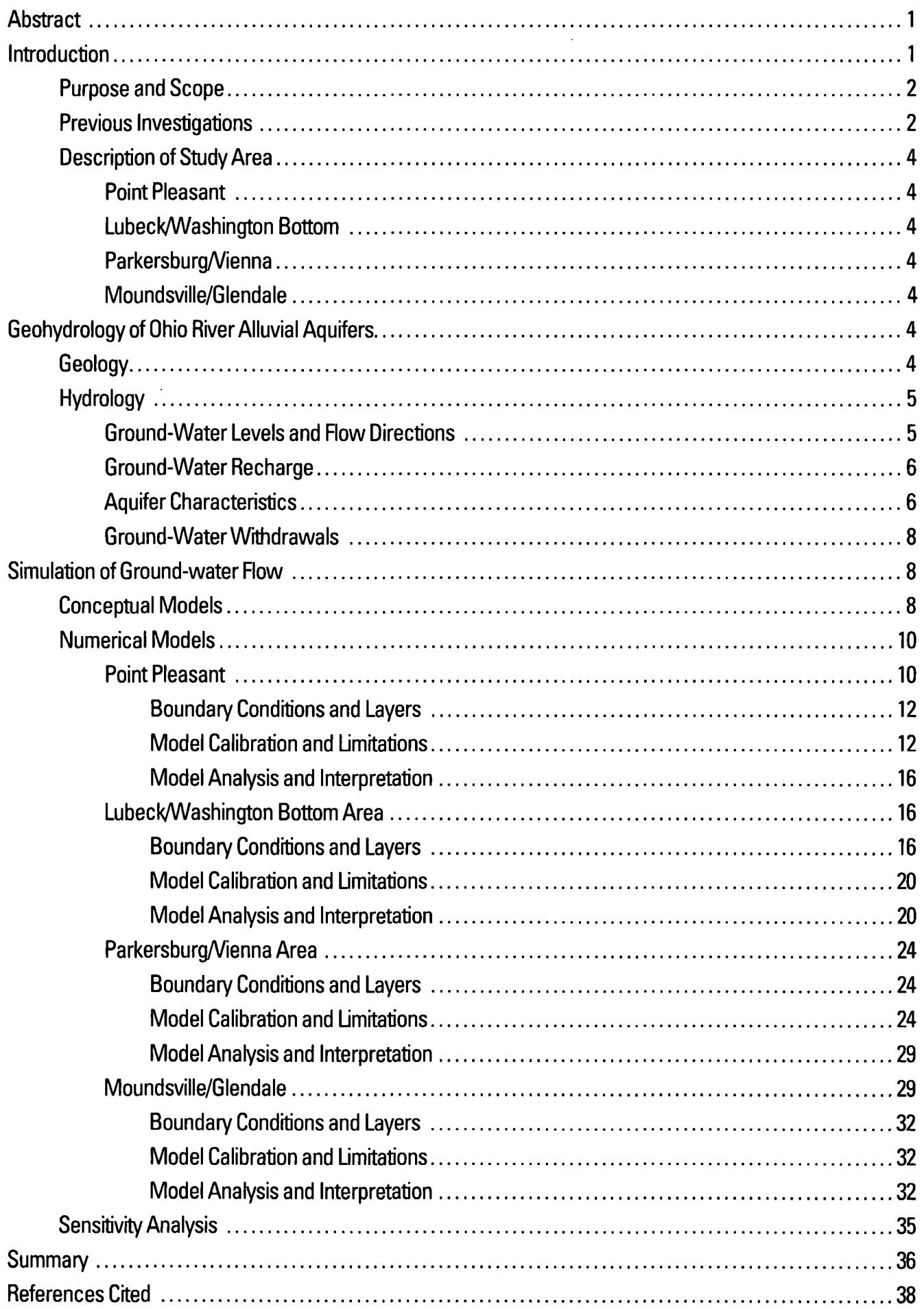




\section{Figures}

1-19. Maps showing:

1. Locations of study areas where ground-water flow was simulated......................... 3

2. Location of the Point Pleasant model area ......................................... 11

3. Values of hydraulic conductivity, inactive cells, and location of production and head observation wells in layers two and three of the Point Pleasant model................. 13

4. Values of hydraulic conductivity, model grid, inactive cells, and location of production and head observation wells in the upper layer of the Point Pleasant model.................. 14

5. Head observation wells and recharge assigned to the upper layer

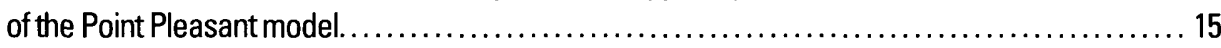

6. Calibrated heads and 5-year time-of-travel paths to the Point Pleasant well field in the lower layer of the model. ................................................ 17

7. Location of the LubeckWashington Bottom model area .................................. 18

8. Values of hydraulic conductivity and location of production and head observation wells in the lower layer of the LubeckWashington Bottom model. ....................... 19

9. Well locations, model grid, inactive cells, and values of hydraulic conductivity in the upper layer of the LubeckWashington Bottom model ............................ 21

10. Head observation wells and recharge assigned to the upper layer of the LubeckWashington Bottom model.......................................... 22

11. Calibrated heads and 5-year time-of-travel paths to the Lubeck well field in the lower layer of the LubeckWashington Bottom model........................... 23

12. Location of the Parkersburg/Vienna model area. ................................... 25

13. Values of hydraulic conductivity and locations of production and head observation wells in the lower layer of the Parkersburg/Nienna model ............................. 26

14. Values of hydraulic conductivity, model grid, and production and head observation wells in the upper layer of the ParkersburgNienna model. ............................. 27

15. Head observation wells and recharge values assigned to the upper layer of the

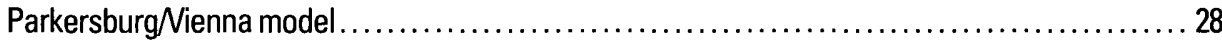

16. Calibrated heads and 5-year time-of-travel paths to the Parkersburg and Vienna well fields in the lower layer of the model ..................................... 30

17. Location of the Moundsville/Glendale model area..................................... 31

18. Model grid, locations of production and head observation wells, and inactive cells for the Moundsville/Glendale model ............................................ 33

19. Calibrated heads and 5-year time-of-travel paths to the Moundsville and Glendale well fields in the lower layer of the model.

\section{Tables}

1. Recharge rates used in ground-water-flow simulations of various alluvial aquifer settings.........6

2. Aquifer characteritics used in ground-water-flow simulations of various alluvial settings ...........7

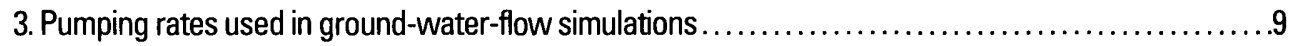

4. Effects of varying parameters for sensitivity analysis during model development and calibration.....35 


\section{Conversion Factors and Datum}

\begin{tabular}{|c|c|c|}
\hline Multiply & By & To obtain \\
\hline \multicolumn{3}{|c|}{ Length } \\
\hline inch (in.) & 2.54 & centimeter $(\mathrm{cm})$ \\
\hline foot $(\mathrm{ft})$ & 0.3048 & meter $(\mathrm{m})$ \\
\hline mile (mi) & 1.609 & kilometer $(\mathrm{km})$ \\
\hline \multicolumn{3}{|c|}{ Area } \\
\hline acre & 0.4047 & hectare (ha) \\
\hline square mile $\left(\mathrm{mi}^{2}\right)$ & 2.590 & square kilometer $\left(\mathrm{km}^{2}\right)$ \\
\hline \multicolumn{3}{|c|}{ Volume } \\
\hline gallons per minute (gpm) & 0.06308 & liters per second $(\mathrm{L} / \mathrm{sec})$ \\
\hline million gallons per day (Mgal/d) & 3,785 & cubic meter $\left(\mathrm{m}^{3} / \mathrm{d}\right)$ \\
\hline inch per year (in/yr) & 2.54 & centimeter per year $(\mathrm{cm} / \mathrm{yr})$ \\
\hline cubic foot $\left(\mathrm{ft}^{3}\right)$ & 0.02832 & cubic meter $\left(\mathrm{m}^{3}\right)$ \\
\hline \multicolumn{3}{|c|}{ Hydraulic conductivity } \\
\hline
\end{tabular}

foot per day $(\mathrm{ft} / \mathrm{d}) \quad 0.3048 \quad$ meter per day $(\mathrm{m} / \mathrm{d})$

Transmissivity*

foot squared per day $\left(\mathrm{ft}^{2} / \mathrm{d}\right) \quad 0.09290 \quad$ meter squared per day $\left(\mathrm{m}^{2} / \mathrm{d}\right)$

Vertical coordinate information is referenced to the insert datum name (and abbreviation) here, for instance, "North American Vertical Datum of 1988 (NAVD 88)."

*Hydraulic Conductivity: The standard unit for hydraulic conductivity is cubic foot per day per square foot of aquifer cross-sectional area $\left(\mathrm{ft}^{3} / \mathrm{d} / \mathrm{ft}^{2}\right)$. In this report, the mathematically reduced form, feet per day ( $\mathrm{ft} / \mathrm{d})$, is used for reference. Likewise, transmissivity, which is the hydraulic conductivity multiplied by the saturated thickness of the aquifer, is expressed in the form square feet per day $\left(\mathrm{ft}^{2} / \mathrm{d}\right)$. 


\title{
Geohydrology and Simulation of Ground-Water Flow in Ohio River Alluvial Aquifers near Point Pleasant, Lubeck, Parkersburg, Vienna, Moundsville, and Glendale, West Virginia
}

\author{
By Mark D. Kozar and Kurt J. McCoy
}

\section{Abstract}

Ground-water flow was simulated for four areas in alluvial aquifers bordering the Ohio River in western West Virginia. The four ground-water-flow models included well fields for the Point Pleasant, Camp Conley, Lubeck, Parkersburg, Vienna, Moundsville, and Glendale public water systems. The models were developed to assess the direction and rate of ground-water flow to public supply wells in the well fields and to assess the effects of large ground-water withdrawals on the ground-waterflow system. The models can be used by water resources managers to develop source-water protection areas for the public supply wells in the study area and in other Ohio River alluvial aquifers. In addition, results of this investigation may be used to help assess the potential rate and movement of nonreactive contaminants in emergency situations, such as a chemical release resulting from a railway or highway accident. Many of the well fields discussed in this report are near transportation corridors and chemical manufacturing facilities.

The alluvial aquifer along the Ohio River has the capacity to yield millions of gallons of water per day to wells completed either in the banks of the Ohio River or as lateral collectors extending beneath the river. Withdrawal of large quantities of ground-water by pumping wells completed in the alluvium can result in large cones of depressions, alter normal flow patterns, and induce infiltration of water from the river towards pumping wells. During high-water events, such as floods, the normal hydraulic gradient can be temporarily altered, and flow to the alluvium from the river can be induced.

Glacial outwash deposits of sand and gravel form the primary aquifer that is tapped as a source of ground water not only for public water systems but also for use by industry, agriculture, commercial facilities, and in rare instances, by residential home owners. Fluvially deposited fine-grained silts and clay, deposited mostly as a result of floods, typically overlie the glacial outwash deposits and form a confining layer. The glacial outwash and fine-grained silt and clay layers form a series of terraces in the alluvium between the Ohio River and the nearby Pennsylvanian and Permian-age bedrock uplands.

Recharge to the alluvium can occur from several sources including seepage from adjacent bedrock, leakage from overlying tributary streams, induced infiltration of water from the Ohio River as a result of pumping, flow from the river to the alluvium due to a reversal of hydraulic gradient during floods, and from precipitation falling on the alluvium. Recharge from adjacent bedrock and leakage from overlying tributary streams was negligible. Induced infiltration of river water and precipitation are the major sources of recharge to the alluvial aquifer. Induced infiltration of water from the Ohio River accounted for various amounts of water pumped from the following well fields: Parkersburg ( 75 percent), Glendale ( 72 percent), Moundsville (50 percent), Lubeck (39 percent), Vienna ( 7 percent), and Point Pleasant (4 percent) well fields. The remainder of the recharge was from precipitation falling on the alluvium. None of the water withdrawn from the Camp Conley well field is derived from infiltration of river water.

Generally, the composition of alluvial sediments along the Ohio River between Huntington, West Virginia and Pittsburgh, Pennsylvania become coarser further to the north. Because the glacial outwash deposits in alluvial flats in the northern part of the study area were closer to the Laurentide Ice Sheet, they are coarser grained than those in the alluvial flats further to the south. Consequently, the hydraulic conductivity of alluvial aquifers to the north (300 to $500 \mathrm{ft}$ per day (ft/d)) are typically higher than those to the south (75 to $300 \mathrm{ft} / \mathrm{d}$ ).

\section{Introduction}

Commercial and industrial facilities, many cities, and some domestic residences rely on the high-yielding alluvial aquifers of the Ohio River for public and industrial water supplies. Wells in this area commonly produce several hundred to thousands of gallons per minute (gpm) of water. Four of he state's largest public ground-water supply systems, which are in Marshall, Mason, and Wood Counties, rely on wells that penetrate the alluvial terraces of the Ohio River. The alluvial terraces consist of poorly to well-sorted sand, silt, clay, and gravel deposits overlying river-scoured Pennsylvanian or Permian-age bedrock. In such highly permeable sediments, numerous sources pose potential threats to ground-water supplies, including pesticides and nitrates from agriculture, pathogens such as bacteria and viruses from leaking sewer lines and septic systems, and industrial chemicals from production and processing plants. In addition, numerous transportation corridors cross the area including railroads, highways, and barge traffic on the Ohio River. Numerous industrial chemicals as well as petroleum products commonly are transported along these corridors 


\section{Ground-Water Flow in Selected Ohio River Alluvial Aquifers, West Virginia}

and could pose potential threats to ground-water supplies if spilled within well-capture zones.

In 1996, amendments to the Safe Water Drinking Act (U.S. Environmental Protection Agency, 2004) were passed to address growing concern of possible contamination of drinkingwater sources. This mandate, enforced by state and federal regulatory agencies, required public ground-water- supply systems to delineate recharge areas as part of the Wellhead Protection Program. Most of the recharge and wellhead protection areas (WHPAs) in the study area had been previously delineated by the West Virginia Bureau for Public Health- Office of Environmental Health Services (WVBPH-OEHS) using simplified analytical ground-water-flow models. Although such simplified analytical models provide a good first approximation of potential WHPAs, they typically cannot effectively simulate groundwater flow in complex hydrogeologic settings. Numerical ground-water-flow modeling using three dimensional models such as the U.S. Geological Survey (USGS) MODFLOW (McDonald and Harbaugh, 1988) software, provides a tool from which more accurate simulations of ground-water flow and delineations of WHPAs can be developed. In 2001, the USGS began a project to develop ground-water-flow models in cooperation with the WVBPH-OEHS. The major objective of this investigation was to assess ground-water-flow rates and directions in alluvial aquifers in four areas along the Ohio River in the western part of West Virginia. The project spanned from January 2001 through December 2003.

\section{Purpose and Scope}

This report presents results from four separate numerical ground-water-flow models of alluvial aquifers along the Ohio River. The models simulate ground-water flow rates and directions and were used to estimate the contribution of water to municipal well fields either from recharge to the alluvium or from induced infiltration of water from nearby streams in Point Pleasant, Lubeck, Parkersburg, Vienna, Moundsville, and Glendale, West Virginia. Five-year time-of-travel zones based on particle tracking are included to assist water-resources managers in delineating source-water protection areas for the public water systems in the modeled areas. Because this report incorporates the likely maximum and minimum extremes in permeability of alluvial sediments likely to be encountered along the entire West Virginia reach of the Ohio River, the results of this study may be applicable to similar alluvial aquifers along the Ohio River in West Virginia, Pennsylvania, and Ohio as far south as Ironton, Ohio.

To determine ground-water-flow directions and time of travel to public water supplies in alluvial aquifers along the Ohio River, some components of the computer program Visual MODFLOW version 2.8.2 (Waterloo Hydrogeologic, 2000) were used. The software is a commercially derived graphical user interface to the USGS MODFLOW-96 three-dimensional finite-difference ground-water-modeling software (Harbaugh and others, 1996). The software also provides an interface to
MODPATH (Winston, 1999), which is a USGS particle-tracking program. Visual MODFLOW was used to simulate groundwater flow and to provide estimates of hydraulic head in the aquifers analyzed. Ground-water-flow directions, rates of flow, effects of ground-water withdrawal, and hydrologic budgets were simulated with the Visual MODFLOW software. Particle tracking, using the MODPATH module of the program, was conducted to estimate flow paths to individual public supply wells.

The models within this report were primarily developed from existing data, especially data from contamination investigations conducted in support of U.S. Environmental Protection Agency (USEPA) RCRA (Resources Conservation and Recovery Act) and CERCLA (Comprehensive Environmental Response, Compensation, and Liability Act) investigations. Due to budget and time constraints, only minimal field data was collected during the course of the investigation, mainly to provide water-level and stream-flow data in areas where such data was not available. A large quantity of aquifer test, well $\log$, water level, and other data was also available from USGS databases and published reports. Finally, well construction, pumpage, and other hydrogeologic data were retrieved from each specific water plant included within this report.

The primary objective of the study was to estimate the rate and direction of ground-water flow by numerical simulation of the alluvial aquifer. A second objective was to simulate groundwater-flow paths to public supply wells using particle-tracking software. These preliminary ground-water-flow models will provide data and information to water-resources managers that will help them delineate wellhead protection areas for public supply wells.

\section{Previous Investigations}

Early ground-water-flow models of the Ohio River alluvium include digital simulations of drawdown in Kentucky by Grubb, (1975) and Kernodle, (1977). A steady-state and transient model of ground-water flow in the Louisville, Kentucky area was completed by Lyverse and others (1991). Unthank $(1996,1998)$ and Unthank and Nelson (1999) modeled alluvial aquifers in northwestern Kentucky to estimate hydraulic properties, recharge, and discharge to the Ohio River. In a threelayer model, the Corporate Remediation Group (2003) simulated ground-water flow at an industrial site in Washington Bottom, West Virginia to evaluate and predict ground-water flow under various pumping stresses. Burgess and Niple (1996) modeled seven scenarios in the Little Hocking, Ohio area to determine WHPAs and to evaluate the fate and transport of potential contaminants in the aquifer. CDM (2002a) prepared a ground-water-flow model for the Vienna area to assess the potential transport of perchloroethylene (PCE) in the aquifer. 


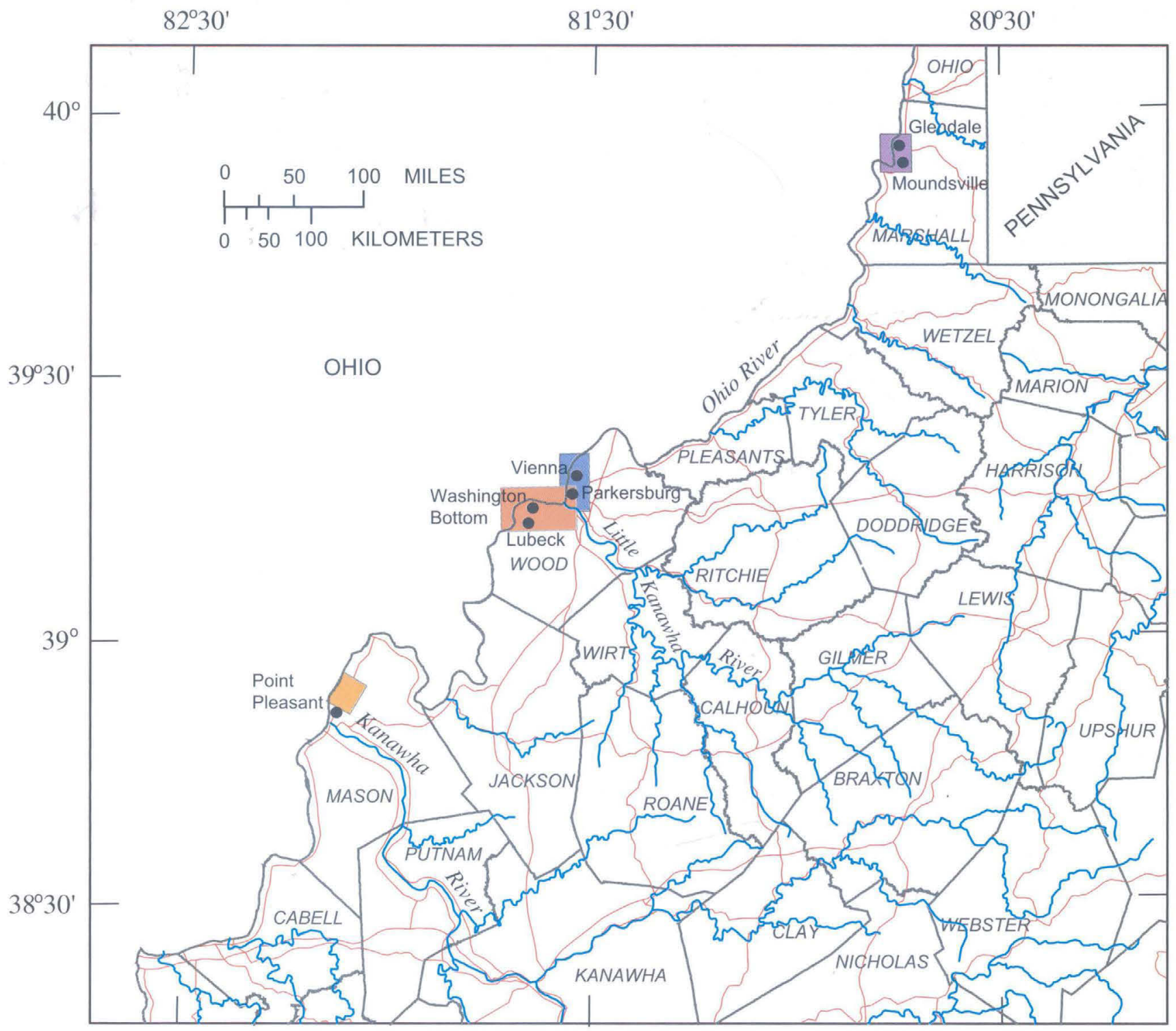

Location in West Virginia

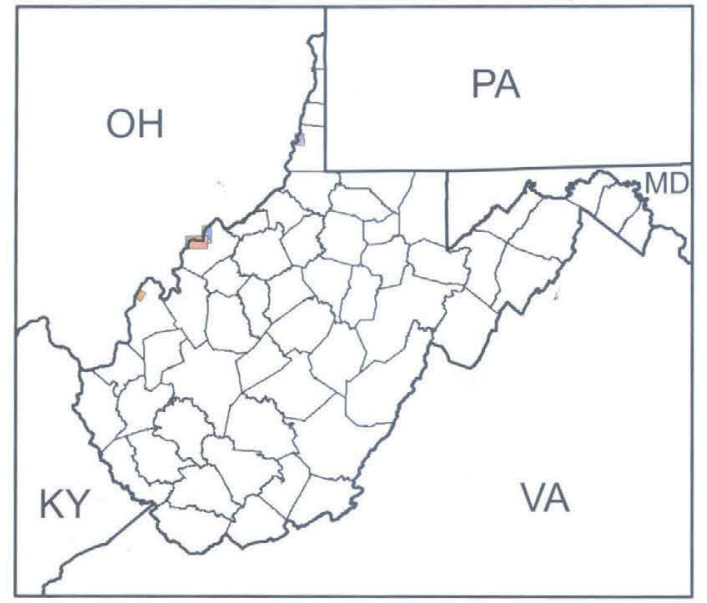

EXPLANATION

Model areas

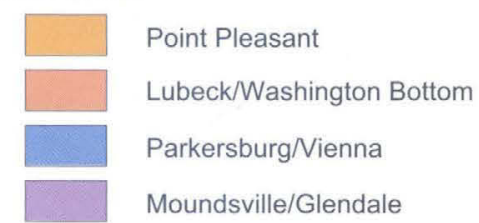

$\square$ County boundaries

Major roads

Major streams

Figure 1. Locations of study areas where ground-water flow was simulated, West Virginia. 


\section{Ground-Water Flow in Selected Ohio River Alluvial Aquifers, West Virginia}

\section{Description of Study Area}

Four alluvial river terraces along the Ohio River, commonly referred to as bottoms, were identified for modeling of ground-water flow to public ground-water-supply systems (fig. 1). Bottom areas are defined as low-lying, flat alluvial deposits along past and present river floodplains. Descriptions of each area are from Carlston and Graeff (1956). The modeled areas are all in the alluvial sand and gravel deposits of the Ohio River and its terraces and extend over a 166-mile (mi) reach of the Ohio River from Point Pleasant in Mason County to Glendale in Marshall County, West Virginia.

\section{Point Pleasant}

The Point Pleasant Bottom in Mason County, West Virginia, is $\mathbf{1 2 . 5} \mathbf{m i}$ long from the mouth of the Kanawha River near the City of Point Pleasant. At its widest point, abandoned river channels extend into the surrounding bedrock hills for up to $2.8 \mathrm{mi}$. Normal pool stage of the river in the area is $538 \mathrm{ft}$. Records from 29 wells in the northern areas show about 30 to $40 \mathrm{ft}$ of sands and gravels overlying the bedrock surface. The sands and gravels are overlain by clays, sands, and sandy clays. In the southern areas, clays and sandy clays cover sands and gravelly sands 25 to $48 \mathrm{ft}$ thick. In the area immediately adjacent to the Point Pleasant well field, confining units typically are absent, and the aquifer is more or less unconfined. Three well tests conducted in the area indicated saturated thicknesses of 28 to $41 \mathrm{ft}$ and a mean hydraulic conductivity of $340 \mathrm{ft} / \mathrm{d}$ (Cross and Schemel, 1956).

\section{LubeckWashington Bottom}

Also called Washington Bottom after original owner George Washington, the Lubeck Bottom is $5.2 \mathrm{mi}$ long and $0.7 \mathrm{mi}$ wide and is in Wood County, West Virginia. The wooded, rural area includes land used for agriculture, chemical and plastic production, and a 250-acre closed solid-waste landfill. The Ohio River normal pool elevation in the area is approximately $582 \mathrm{ft}$. Test borings show basal sands and gravels 19 to $77 \mathrm{ft}$ thick overlain by 14 to $35 \mathrm{ft}$ of clays, sandy clays, and silts. Thicker sands and gravels are found under higher terraces. An aquifer test conducted by the USGS yielded an estimated. hydraulic conductivity of approximately $334 \mathrm{ft} / \mathrm{d}$ (Cross and Schemel, 1956).

\section{Parkersburg/Vienna}

The Parkersburg/Vienna Bottom extends north $6.5 \mathrm{mi}$ from the mouth of the Little Kanawha River. Its width is $0.8 \mathrm{mi}$, narrowing toward the small town of Vienna. Normal pool elevation at the dam is approximately $582 \mathrm{ft}$. Parkersburg and Vienna are just north of the Lubeck/Washington Bottom area and are also in Wood County. Three test borings at the dam show fine to coarse sands and gravels $25-27 \mathrm{ft}$ thick, overlain by loam and clay in places. At the Parkersburg well field, the alluvium thins to about $60 \mathrm{ft}$, containing 15 to $25 \mathrm{ft}$ of permeable sands and gravels overlain by varying thicknesses of fine sand, silt, and clay (Jeffords, 1945). Overlying clays and silty clays are generally 5 to $15 \mathrm{ft}$ thick. Aquifer tests conducted at four locations in the Parkersburg area indicate a mean hydraulic conductivity near $850 \mathrm{ft} / \mathrm{d}$ and saturated thickness of approximately $21 \mathrm{ft}$ (Cross and Schemel, 1956). Land use on the alluvium in Parkersburg and Vienna is highly developed with numerous commercial and industrial facilities and residential homes.

\section{Moundsville/Glendale}

The Moundsville/Glendale Bottom is a cut-off meander channel extending $3.5 \mathrm{mi}$ along the Ohio River in Marshall County, West Virginia. The predominantly residential Glendale occupies the relatively narrow ( $0.5 \mathrm{mi}$ wide) northern part of the bottom. By comparison, a broad circular southern part at Moundsville has a width of more than $3 \mathrm{mi}$. Normal pool stage of the Ohio River in the area is approximately $623 \mathrm{ft}$. Well depths range from 70 to $100 \mathrm{ft}$ and wells are known to have penetrated $100 \mathrm{ft}$ of gravel near the middle of the meander (Cross and Schemel, 1956). Pumping rates above $100 \mathrm{gal} / \mathrm{min}$ are typical for industrial wells drilled in the thick gravel bed. Saturated thicknesses generally range from 30 to $40 \mathrm{ft}$.

\section{Geohydrology}

The geology of the four study areas is typified by highly permeable sand and gravel glacial outwash deposits. The deposits have the capacity to yield millions of gallons of water per day to wells, especially to wells completed in river-bank deposits or completed as long, horizontal, radial-collector wells extending beneath the river bed. Residents of the Ohio River Valley have been withdrawing water from wells completed in these sediments since the mid-to late 1800's.

\section{Geology}

Alluvial aquifers of the Ohio River have been of interest for more than 100 years. Hennen (1909), Grimsley (1910), and Krebs (1911) provided county reports with detailed geologic information including lithologic, stratigraphic, and structural data of the study area along the Ohio River. Deutsch and others (1966) published a comprehensive survey of ground-water resources for the Ohio River Basin and several of its larger tributaries. The West Virginia Geological and Economic Survey (WVGES) produced a three-part report including a description of Ohio Valley geology in West Virginia by Cross and Schemel (1956) and ground-water resources of the Ohio Valley in West Virginia by Carlston and Graeff (1956).

The Ohio River follows a gentle gradient along the border between West Virginia and Ohio for $277 \mathrm{mi}$ before it reaches 
Kentucky. Hilly terrain of south-southeast dipping Lower Permian and Pennsylvania-age rocks is dominant in the upland areas and gives way to a flood plain less than $500 \mathrm{ft}$ below. Lower Permian and Pennsylvanian bedrock consists of cyclic groups of interbedded sandstones, shales, limestones, clays, and coals (Cross and Schemel, 1956). Local rises in bedrock elevation have been ascribed to changes from older limestone strata to younger more resistant sandstones (Cross and Schemel, 1956).

Pleistocene alluvium from glacial outwash deposits of the pre-, early-, and late-Wisconsinan age have been reworked and deposited at lower elevations forming terraces (Simard, 1989). Carlston and Graeff (1956) found the maximum thickness of the alluvium beneath the highest terraces is $120 \mathrm{ft}$, and that the thickness of the alluvium generally decreases in the downstream direction.

Pleistocene sands and gravels directly overlying the bedrock surface are thought to be the result of continental glaciation of the northern Ohio River headwaters. Jeffords (1945) suggested these sediments are from 15 to $25 \mathrm{ft}$ thick in well-fields in the Parkersburg area. Pleistocene sand and gravels in Marshall County to the north are similar in thickness (Cross and Schemel, 1956). Hall (1917) found sediments in Parkersburg to be firmly cemented in the $18 \mathrm{in}$. above bedrock.

Heterogeneous alluvial deposits ranging from gravels to clays overlie the Pleistocene glacial deposits. Generally, the alluvium thickens away from valley walls and near the mouth of tributary streams. North of Parkersburg, the alluvial fill consists mainly of gravels, sands, and gravelly sands whereas fine sands, silts, and clays dominate sediments downstream from Parkersburg. Lenticular interbeds of varying composition are not uncommon throughout the alluvium (Cross and Schemel, 1956). Surface sediments consist of fine-grained sands to silts and clays of Holocene age and average $10 \mathrm{ft}$ in thickness, sometimes up to $40 \mathrm{ft}$ in the flood plain (Cross and Schemel, 1956). This poorly permeable layer serves to limit recharge from precipitation, and in places acts as a confining layer (Cross and Schemel, 1956). Simard (1989) identified a sequence of five river terraces formed as the channel shifted back and forth cutting into the Wisconsinan deposits. Three flood plains also were identified. Radiocarbon ages of the fluvial and alluvial sediments ranged from 5,000 years to more than 40,000 years (Simard, 1989).

\section{Hydrology}

The high-yielding alluvial aquifers of the Ohio River Valley have been extensively studied. Jeffords (1945) was one of the first to investigate the effect of river stage on ground-water levels in the adjacent alluvium. He concluded that a large amount of recharge to the alluvial aquifer was derived from the river when the Ohio River was at high stage. Induced infiltration from the Ohio River to pumping wells in the aquifer is likely where such wells are close to the river, although local heterogeneity of river-bottom sediments may reduce the connec- tion (Mathes and others, 1995; Jeffords, 1945). Tributaries to the Ohio River may provide additional recharge as they flow across alluvial and fluvial deposits (Mathes and others, 1995).

Recharge from tributary streams to underlying alluvial aquifers in the region has not been well quantified. Discharge was measured at two tributary streams during this investigation both at the point where the streams flowed onto the alluvium and at a second point just prior to discharge to the Ohio River. Both streams are characteristic of streams which flow across alluvium and discharge to the Ohio River. The change in flow was not appreciable between upstream and downstream sites on either stream. This may indicate that tributary streams are armored to a certain extent suggesting tributary recharge is negligible in most cases. Also, throughout the region, ground-water levels typically are far below the base of tributary streams and significant gains or losses to and from streamflow are not anticipated.

In the absence of significant recharge from tributary streams and from bedrock, the majority of recharge under ambient conditions is likely from precipitation. A large percentage of precipitation is lost to surface runoff and evapotranspiration. Evapotranspiration in the Louisville, Kentucky, area accounted for 65 percent of precipitation; the remaining 35 percent was almost equally divided between infiltration and runoff (Rorabaugh, 1949). Infiltration from the river can occur naturally when local hydraulic gradients are reversed during high river stages, which is common during floods, typically in winter and spring. Under base-flow conditions, however, hydraulic gradients generally are from the alluvium towards the river. Discharge from surrounding bedrock aquifers serves as an additional source of recharge but is likely small in comparison to that derived from precipitation (Mathes and others, 1995).

In a survey of 183 wells in Ohio River alluvium of West Virginia, Kozar and Mathes (2001) found an average saturated thickness of $35.6 \mathrm{ft}$ and average static water level of $43 \mathrm{ft}$ below land surface. Well yields ranged from 30 to $5,500 \mathrm{gal} / \mathrm{min}$. In a test of 19 wells, transmissivity of the aquifer ranged from 130 to 1,750 square $\mathrm{ft}$ per day $\left(\mathrm{ft}^{2} / \mathrm{d}\right)$ with average saturated thickness of $25 \mathrm{ft}$ between Parkersburg and Point Pleasant (Carlston and Graeff, 1956). Transmissivity ranged from 540 to 59,000 $\mathrm{ft}^{2} / \mathrm{d}$ in wells analyzed by Kozar and Mathes (2001). The same report provided a median storage coefficient of 0.20 for Ohio River alluvium, indicative of an unconfined aquifer. Mean transmissivities of $750,4,200$, and $7,500 \mathrm{ft}^{2} / \mathrm{d}$ were reported by Corporate Remediation Group (2003), Mathes and others (1995), and Burgess and Nipple (1996), respectively.

\section{Ground-Water Levels and Flow Directions}

Ground-water levels vary throughout the alluvium but generally indicate a hydraulic gradient towards the Ohio River under normal conditions (Kazmann and others, 1943). Under normal pool conditions, in the absence of significant pumping, hydraulic gradients are almost exclusively towards the river. Exceptions occur during floods or other high-water events. 
When the stage of the Ohio River increases markedly over a short period of time such as during a flood, a reversal in the normal hydraulic gradient occurs and river water can flow into and recharge the alluvium. These effects usually are very short in duration and are not believed to significantly alter the hydrologic budget in the alluvium; however, such effects may have pronounced effects on the flow of contaminants in the alluvium. In addition, large pumping centers can cause very large cones of depression to form, which may result in lowering the water level in the aquifer to levels below that of the normal pool stage of the Ohio River.

\section{Ground-Water Recharge}

Estimates of ground-water recharge for alluvial aquifers bordering the Ohio River are highly variable. An early estimate of recharge for the alluvial aquifer near Louisville, Kentucky was 9.2 inches per year (in/yr) (Rorabaugh, 1949). Estimates of recharge for bedrock aquifers in the region based on streamflow hydrograph analysis ranged from 6.7 to $9.6 \mathrm{in} / \mathrm{yr}$ (Kozar and Mathes, 2001), or 16 to 24 percent of the average annual precipitation of $40.7 \mathrm{in.}$ (NOAA, 2002) at Parkersburg. Recharge rates for alluvial aquifers with little silt or clay could be potentially much higher. A calibrated ground-water-flow model for the Vienna area from prior modeling studies indicated recharge rates in the range from 6.9 to $11.5 \mathrm{in} / \mathrm{yr}$ (CDM Corporation, $2002 b$ ). Results of calibrated ground-water-flow models in the Washington Bottom area near Lubeck ranged from 4 in/yr on Holocene flood plains to $20 \mathrm{in} / \mathrm{yr}$ in colluvial deposits near the margins with upland bedrock outcrops at the edge of the valley (Corporate Remediation Group, 2003). A test conducted in the Weirton area for a large collector well assumed a recharge rate of approximately $11.4 \mathrm{in} / \mathrm{yr}$ (Ranney Corporation, 1981). In the wellhead protection plan for the Little Hocking, Ohio, well field, a recharge rate of $12 \mathrm{in} / \mathrm{yr}$ was assumed (Burgess and Niple, 1996). Estimates of ground-water recharge for alluvial aquifers along the Ohio River in West Virginia applied to models in this report range from 0.1 to $11.8 \mathrm{in} / \mathrm{yr}$ (Table 1) and vary based on the composition of the alluvium in certain areas. Alluvial deposits with a high percentage of sand and gravel tend to have recharge rates approaching $12 \mathrm{in} / \mathrm{yr}$ whereas deposits with a large percentage of silt and clay may be as low as $3 \mathrm{in} / \mathrm{yr}$.

In addition to recharge from precipitation, the alluvial aquifers along the Ohio River also may receive significant infiltration directly from the Ohio River and possibly to a minor extent from tributary streams crossing the alluvium (Jeffords, 1945). As previously discussed, induced infiltration can take place under two scenarios, either when the cone of depression for a pumping well lowers water levels in the aquifer to depths below the stage of the Ohio River or when the normal hydraulic gradient is reversed due to flooding or high river stages.

Induced infiltration of water directly from the Ohio River can contribute the majority of water yielded to wells, especially from large collector wells, which may far exceed that possible from precipitation alone.
Table 1. Recharge rates used in ground-water-flow simulations of various alluvial aquifer settings.

[in/yr, inches per year]

\begin{tabular}{lc}
\hline \multicolumn{1}{c}{ Description of model areas } & $\begin{array}{c}\text { Recharge rate } \\
\text { (in/yr) }\end{array}$ \\
\hline \multicolumn{1}{c}{ Parkersburg/Nienna Area } & 6.0 \\
\hline Parkersburg well field and lower terraces & 3.0 \\
Parkersburg upper terraces & 9.0 \\
Vienna Wellfield & \\
Point Pleasant Area & 11.0 \\
Point Pleasant oxbow & 12.0 \\
Point Pleasant well field and lower terraces & \\
\hline \multicolumn{1}{c}{ Lubeck Area } & 7.0 \\
\hline Lubeck well field & 9.8 \\
Washington Bottom upper terraces & 11.0 \\
Blennerhassett Island & 0.1 \\
Reworked Ohio River bottom sediments & 11.0 \\
\hline \multicolumn{1}{c}{ Moundsville/Glendale Area } \\
\hline Moundsville well field & 11.0 \\
\hline Glendale well field &
\end{tabular}

\section{Aquifer Characteristics}

Aquifer characteristics are hydraulic properties of aquifers and include transmissivity, hydraulic conductivity, saturated thickness, storativity, porosity, and depth to water. For alluvial aquifers along the Ohio River, existing data and reports were compiled and used for simulating ground-water flow and for particle tracking. The alluvial aquifers bordering the Ohio River vary in the composition of sediments but generally share many common characteristics. All the aquifer characteristics used for the simulations described in this report are listed in table 2 . The only aquifer characteristic that changes to a significant degree in the alluvium is hydraulic conductivity. Because glacial outwash deposits in the northern part of the study area are composed of coarser grained sediments than the alluvial deposits further to the south, the transmissivity and hydraulic conductivity of alluvial flats to the north typically are higher than those to the south. Fine-grained flood-plain sediments of fluvially deposited silt and clay overlie the coarser grained glacial outwash deposits in many areas (Simard, 1989). 
Table 2. Aquifer characteritics used in ground-water-flow simulations of various alluvial settings.

[ft, feet; bls, below land surface; $\mathrm{ft}^{-1}$, reciprocal feet; $\mathrm{ft} / \mathrm{d}$, feet per day; $\mathrm{n} / \mathrm{a}$, not applicable].

\begin{tabular}{|c|c|c|c|c|}
\hline Model areas & $\begin{array}{c}\text { Hydraulic } \\
\text { conductivity } \\
\text { (ft/d) }\end{array}$ & $\begin{array}{c}\text { Thickness of } \\
\text { alluvium } \\
\text { (ft) }\end{array}$ & $\begin{array}{l}\text { Depth to } \\
\text { water } \\
\text { (ft bls) }\end{array}$ & Porosity \\
\hline \multicolumn{5}{|c|}{ Point Pleasant Area } \\
\hline Point Pleasant well field & 350 & $75-95$ & $40-55$ & 0.30 \\
\hline Point Pleasant oxbow & 87 & $55-75$ & $41-55$ & .35 \\
\hline Camp Conley well field & 83 & $75-95$ & $42-48$ & .30 \\
\hline Point Pleasant confining unit & 0.1 & $39-58$ & $9-45$ & .35 \\
\hline \multicolumn{5}{|c|}{ Lubeck/Washington Bottom Area } \\
\hline Lubeck well field & 190 & $60-85$ & $24-35$ & .30 \\
\hline Washington Bottom well fields & 190 & $60-65$ & $33-40$ & .30 \\
\hline Washington Bottom confining unit & $1-4$ & $80-105$ & $60-80$ & .35 \\
\hline Washington Bottom colluvium & 190 & $85-95$ & $65-80$ & .30 \\
\hline Blennerhassett Island well field & 250 & $50-58$ & $27-40$ & .30 \\
\hline Blennerhassett Island confining unit & 20 & $0-15$ & $27-40$ & .30 \\
\hline $\begin{array}{l}\text { Reworked Ohio River bottom sedi- } \\
\text { ments }\end{array}$ & 15 & $45-55$ & $\mathrm{n} / \mathrm{a}$ & .30 \\
\hline \multicolumn{5}{|c|}{ Parkersburg/Vienna Area } \\
\hline Parkersburg well field & 175 & $45-65$ & $30-40$ & .30 \\
\hline Parkersburg confining unit & $1-2$ & $65-95$ & $50-68$ & .35 \\
\hline Vienna well field & 300 & $70-80$ & $30-58$ & .30 \\
\hline Vienna confining unit & 3 & $65-100$ & $50-68$ &. .35 \\
\hline \multicolumn{5}{|c|}{ Moundsville/Glendale Area } \\
\hline Moundsville well field & 500 & $55-80$ & $20-30$ & .30 \\
\hline Glendale well field & 500 & $65-85$ & $30-40^{\circ}$ & .30 \\
\hline Moundsville confining unit & 1 & $65-90$ & $30-55$ & .35 \\
\hline Glendale confining unit & 1 & $65-100$ & $30-55$ & .35 \\
\hline
\end{tabular}




\section{Ground-Water Withdrawals}

Ground water is withdrawn from Ohio River alluvial aquifers for many purposes including public water supplies, publicservice water districts in rural areas, irrigation of crop land, industrial water for processing, power-plant cooling water, and less commonly, for small commercial and domestic supplies. For this investigation, ground-water-flow models were developed mostly for large municipalities in Point Pleasant, Lubeck, Parkersburg, Vienna, Moundsville, and Glendale, West Virginia and for the Camp Conley Public Service District in Mason County. Average rates of ground-water withdrawal for these systems and the few smaller point sources near these well fields are listed in table 3 .

The largest public supplier in the study area is the City of Parkersburg that withdraws approximately $4,800,000$ gallons per day (gal/d) of water and the smallest supplier is the Camp Conley Public Service Water District which withdraws only $34,000 \mathrm{gal} / \mathrm{d}$. Two large chemical manufacturing facilities in the area immediately north of the Lubeck well field withdraw approximately $8,800,000 \mathrm{gal} / \mathrm{d}$ and 2,060,000 $\mathrm{gal} / \mathrm{d}$, respectively. Such large withdrawals are common for industrial sites along the Ohio River and include facilities that manufacture steel, plastics, chemicals, and other products.

\section{Simulation of Ground-Water Flow}

Ground-water flow for four distinct alluvial aquifers that border the Ohio River in West Virginia was simulated for this investigation. The modeled areas from south to north are 1) Point Pleasant in Mason County, 2) Lubeck and Washington Bottom in Wood County, 3) Parkersburg and Vienna in Wood County, and 4) Moundsville and Glendale in Marshall County. The four model areas are in an approximate 150-mi stretch of the Ohio River in West Virginia. Where appropriate, model simulations include parts of the alluvial aquifer in Ohio. This was done to assess the effects of pumping centers on either side of the Ohio River on the hydraulic head distribution throughout the aquifer. Large pumping centers on one side of the Ohio River may affect head distribution in the alluvial aquifer on the opposing bank if large amounts of water are withdrawn from the aquifer. This is the case for the Lubeck/Washington Bottom and the Parkersburg/Vienna models. Pumping in the Point Pleasant and Moundsville/Glendale areas was not sufficient to have major effects on head distributions in the aquifer. Also, alluvial sediments are not exposed on the Ohio side of the river in these areas.

\section{Conceptual Models}

The conceptual model of ground-water flow for the four areas outlined in this report is fairly straightforward. Because the alluvial materials are primarily sand and gravel with overlying deposits of silts and clays, the aquifer is expected to be homogenous. Some variability between vertical and hydraulic conductivity is expected due to stratification in the aquifer as thin lenses of clay or sand are commonly interspersed in the sand and gravel aquifer matrix. Overall, flow in the aquifer should meet assumptions of Darcian flow.

Flow to the aquifer is possible from several sources including infiltration of precipitation (recharge), bedrock seepage, direct infiltration from the Ohio River during floods, and leakage from tributary streams crossing alluvial sediments. For the areas described in this report, seepage from bedrock aquifers was not considered a major source of inflow because the hydraulic conductivity of bedrock aquifers in the region is typically low when compared to that of the alluvial aquifers. Seepage from bedrock aquifers was therefore not simulated in any of the models. Although infiltration of flood waters from the Ohio River may be a source of water to the aquifer, under normal conditions most ground water discharges to the river. Where pumping wells are near the river, induced infiltration of water directly from the river is common. Seepage from overlying tributary streams to the underlying alluvial aquifer is considered minimal based on discharge measurements made during this investigation and the fact that most tributary streams in the modeled areas were dry for substantial periods during this investigation. Precipitation is therefore the main source of recharge to the alluvial aquifers.

Of the 40.7 inches of precipitation (NOAA, 2002) that typically falls annually on the area, 9-12 in. may be expected to infiltrate and recharge alluvial aquifers, with lesser amounts of recharge in areas characterized by thick sequences of silt and clay. The remaining 28.7 to $31.7 \mathrm{in}$. of precipitation is either lost to streams as surface runoff or lost to evaporation or transpiration by plants. For bedrock-dominated streams in the region, total streamflow averages 18.7 (in/yr). Of the $18.7 \mathrm{in} / \mathrm{yr}$, approximately 11.7 in. (29 percent) is attributed to baseflow discharge and 7 in. (17 percent) is attributed to surface runoff. Evapotranspiration would therefore account for approximately 22.0 in. (54 percent) of the precipitation lost annually. Most recharge takes place in the colder months from November through April when evaporation and transpiration by plants are minimal. Only minor amounts of ground-water recharge typically occur in the warmer months under normal conditions.

Under normal conditions, ground water is expected to flow from upland terraces towards the Ohio River or adjacent tributary streams (Kazmann and others, 1943). This flow pattern can be altered by two processes. First, large cones of depression may form around pumping centers withdrawing large volumes of water (Kazmann and others, 1943). This large cone of depression would be expected for large water systems withdrawing millions of gallons of water per day. Smaller systems that only withdraw a few tens of thousands of gallons of water per day that would have flowed to the river would not be expected to produce cones of depressions large enough to cause a significant flow of water from the river into the alluvium. The second process that may alter the typical ground-water-flow gradient are high water events, especially during floods. During a high-water event on the Ohio River, water levels in the aquifer 
Table 3. Pumping rates used in ground-water-flow simulations.

[gal/d, gallons per day; map id, map identifier as used on illustrations within this report].

\begin{tabular}{|c|c|c|c|}
\hline Local well name (map id) & $\begin{array}{l}\text { Pumping rate } \\
\text { (gal/d) }\end{array}$ & Local well name (map id) & $\begin{array}{c}\text { Pumping rate } \\
\text { (gal/d) }\end{array}$ \\
\hline \multicolumn{2}{|c|}{ Parkersburg/Vienna Area } & \multicolumn{2}{|c|}{ Lubeck/Washington Bottom Area } \\
\hline Parkersburg Collector \# 1 (1) & $1,274,933$ & Chemical Plant \#2 - Well 1 (18) & 144,010 \\
\hline Parkersburg Collector \# 4 (2) & $1,274,933$ & Chemical Plant \#2 - Well 2 (19) & 158,411 \\
\hline Parkersburg Collector \# 3 (4) & $1,147,440$ & Chemical Plant \#2 - Well 3 (21) & 172,812 \\
\hline Parkersburg Collector \# 5 (3) & $1,083,694$ & Chemical Plant \#2 - Well 4 (17) & 144,010 \\
\hline Vienna \# 7 (15) & 204,750 & Chemical Plant \#2 - Well 5 (16) & 144,010 \\
\hline Vienna \# $8(8)$ & 204,750 & Chemical Plant \#2 - Well 6(20) & 144,010 \\
\hline Vienna \# 9 (5) & 204,750 & Chemical Plant \#2 - Well 7 (9) & 144,010 \\
\hline Vienna \# $10(6)$ & 204,750 & Chemical Plant \#2 - Well 8 (8) & 144,010 \\
\hline Vienna \# 11 (14) & 195,300 & Chemical Plant \#2 - Well 9(7) & 144,010 \\
\hline Vienna \# 13 (12) & 195,300 & Chemical Plant \#2 - Well 10 (14) & 144,010 \\
\hline Vienna \# 14 (13) & 195,300 & Chemical Plant \#2 - Well 11 (13) & 144,010 \\
\hline Golf Course \# 1 (11) & 20,000 & Chemical Plant \#2 - Well 12 (12) & 144,010 \\
\hline Golf Course \# 2(10) & 63,330 & Chemical Plant \#2 - Well 13 (11) & 144,010 \\
\hline Plant Well (7) & 29,900 & Chemical Plant \#2 - Well 14 (10) & 144,010 \\
\hline Church Well (9) & 65,000 & & \\
\hline \multicolumn{2}{|c|}{ Lubeck/Washington Bottom Area } & \multicolumn{2}{|l|}{ Point Pleasant Area } \\
\hline Lubeck - Well A (6) & 110,841 & Point Pleasant Well \# 7 (5) & 115,200 \\
\hline Lubeck - Well B (5) & 110,841 & Point Pleasant Well \# 1 (4) & 241,000 \\
\hline Lubeck - Well C (4) & 110,841 & Point Pleasant Well \# 2 (3) & 262,800 \\
\hline Lubeck - Well D(3) & 110,841 & Point Pleasant Well \# 3 (2) & 262,800 \\
\hline Lubeck - Well E (2) & 110,841 & Point Pleasant Well \# 4 (1) & 208,800 \\
\hline Lubeck - Well F (1) & 110,841 & Camp Conley PSD Well (6) & 34,000 \\
\hline Chemical Plant \#1 - Well 1 (22) & 98,921 & & \\
\hline Chemical Plant \#1 - Well 2 (23) & 98,921 & \multicolumn{2}{|c|}{ Moundsville/Glendale Area } \\
\hline Chemical Plant \#1 - Well 3 (24) & 98,921 & Recovery Well (10) & 824 \\
\hline Chemical Plant \#1 - Well 4 (15) & 98,921 & Glendale \# 1 (7) & 131,000 \\
\hline Chemical Plant \#1 - Well 5 (25) & 98,921 & Glendale \# 2 (6) & 131,000 \\
\hline Chemical Plant \#1 - Well 6(26) & $1,273,889$ & Hospital \# 1 (8) & 35,250 \\
\hline
\end{tabular}


Table 3. Pumping rates used in ground-water-flow simulations.-Continued

[gal/d, gallons per day; map id, map identifier as used on illustrations within this report].

\begin{tabular}{cclc}
\hline Local well name (map id) & $\begin{array}{c}\text { Pumping rate } \\
\text { (gal/d) }\end{array}$ & \multicolumn{1}{c}{ Local well name (map id) } & $\begin{array}{c}\text { Pumping rate } \\
\text { (gal/d) }\end{array}$ \\
\hline Chemical Plant \#1 - Well 7 (27) & 120,530 & Hospital \# 2 (9) & 35,250 \\
Chemical Plant \#1 - Well 8 (28) & 229,280 & Moundsville \# 14(1) & 358,000 \\
Chemical Plant \#1 - Well 9 (29) & 99,969 & Moundsville \# 8(2) & 572,000 \\
Chemical Plant \#1 - Well 10(31) & 355,248 & Moundsville \# 12(3) & 428,000 \\
Chemical Plant \#1 - Well 11 (32) & 212,107 & Moundsville \# 12a (4) & 572,000 \\
Chemical Plant \#1 - Well 12 (30) & 292,275 & Moundsville \# 9(5) & 428,000 \\
\hline
\end{tabular}

would be expected to rise to above normal levels. This would result in a temporary reversal of the normal gradient and cause water to infiltrate the alluvium from the adjacent Ohio River. These events are short in duration (typically only a few days) and result in only a temporary change in the hydraulic gradients in the alluvium. Water levels would return to normal quickly after the Ohio River stage had receded to normal pool stage.

\section{Numerical Models}

Visual MODFLOW Version 2.8.2 (Waterloo Hydrogeologic, Inc., 2000) was used in this study to simulate groundwater flow. This program incorporates MODFLOW-96 (Harbaugh and McDonald, 1996), which is a three-dimensional ground-water-flow model, and MODPATH (Winston, 1999), which is a particle-tracking routine. Both software packages were developed by the USGS. Visual MODFLOW is an enhanced version of MODFLOW-96 that includes MODPATH with additional graphical user interfaces attached to aid model use.

The normal assumptions with regard to ground-water flow in porous media were considered applicable to the study area. Ground-water flow is assumed to be laminar. The aquifers simulated were also assumed to be homogenous and isotropic in representative cells; on a larger scale, local variability in aquifer properties has a negligible effect on the overall rate and direction of simulated ground-water flow. Stratified lenticular deposits of silt and clay occur locally in the aquifer and result in a horizontal hydraulic conductivity that is several times more permeable than in the vertical direction. Although this difference between horizontal and vertical hydraulic conductivity has not been quantified in the study areas, a horizontal-to-vertical hydraulic conductivity ratio of approximately 10:1 was used for all ground-water simulations.

All simulations of ground-water flow for this investigation were developed as steady-state models. Transient effects were not considered to be a major concern, because the models did not incorporate storage or solute transport. Transient effects, such as rising stages on the Ohio River, have an effect on ground-water flow but their occurrence and duration are so infrequent and short that a steady-state model can effectively simulate ground-water flow for the four modeled areas. However, estimates of the 5-year time-of-travel paths to public supply wells were made as part of the steady-state models developed for this investigation. The modeled areas were generally selected where extensive pre-existing hydrogeologic data sets were available. Data-collection activities were kept to a minimum due to the large amount of available data for most study areas. Field data-collection activities performed during this project concentrated on investigating hydrologic processes that were poorly understood, such as the effect of tributary streams, and on compiling well construction, maintenance, and pumping records from the major public, industrial, and commercial water suppliers in the modeled areas. Only the Moundsville/Glendale and Parkersburg areas required field investigations to document water levels for calibration purposes.

Particle-tracking routines used in this investigation require data on aquifer porosity. Unfortunately, few data are available documenting the porosity of sediments in alluvial deposits along the Ohio River. Nevertheless, the sediments are similar to many sand and gravel deposits in other areas in the country. Average porosity for alluvial sediments generally ranges from 25 to 50 percent for sand and gravel and from 35 to 70 percent for silt and clay (Freeze and Cherry, 1979). Values of porosity of 25-30 percent were applied to coarse-grained sediments. Values of 30-35 percent were applied to fine-grained sediments to construct the ground-water-flow models.

\section{Point Pleasant}

The Point Pleasant model extends from the Bellmeade area on the north side of Point Pleasant, West Virginia near Ohio River mi 262. north to Eightmile Island and Ohio River mi 256. (fig. 2). The model area includes the Bellmeade area of Point 


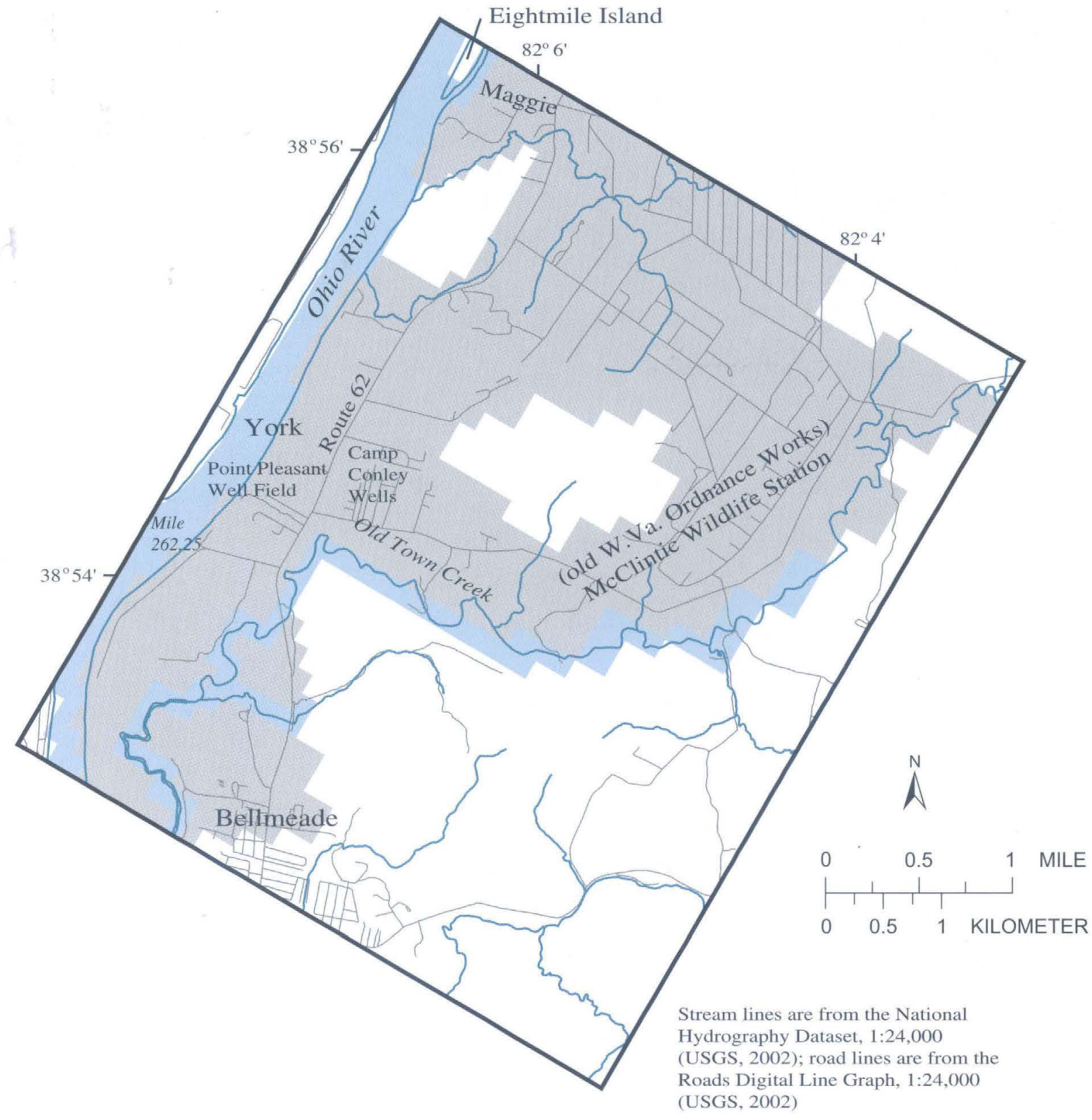

EXPLANATION

- Roads

- Streams

$\square$ Model boundary
Model cell assignment

River

Active

Inactive

Figure 2. Location of the Point Pleasant model area, West Virginia (refer to figure 1 for general location map). 


\section{Ground-Water Flow in Selected Ohio River Alluvial Aquifers, West Virginia}

Pleasant, the southern part of the community of Maggie, the McClintic Wildlife Management area, and the Point Pleasant and Camp Conley Public Service District (PSD) well fields. A large part of the area once comprised the Point Pleasant Ordnance Works where explosives were manufactured during World War II (Kazmann and others, 1943).

Ground-water and soil contamination have been documented at several locations near the Point Pleasant and Camp Conley PSD well fields, primarily resulting from activities at the old Ordnance Works and a nearby manufacturing facility (Peter Costello, West Virginia Department of Environmental Protection, written commun., 2000). As a result of the groundwater and soil contamination at these primary sites, several hydrogeologic assessments have been conducted in support of USEPA RCRA and CERCLA investigations. A site-wide hydrogeological study of the Point Pleasant Ordnance Works (IT Corporation, 1996) included borehole logs, water-level measurements, aquifer tests, and water-quality data. An initial hydrogeologic assessment of the facility was conducted by the USGS during World War II to provide for expansion of operations (Kazmann and others, 1943). Additional data obtained included Ohio River depth soundings and bottom maps (Kent Browning, U.S. Army Corps of Engineers, written commun., 2000) and borehole logs and pumping records for the Point Pleasant Water Plant (Dan Rogers, Point Pleasant Water Department, written commun., 2000). Additional data used to calibrate and develop the ground-water-flow model for the Point Pleasant and Camp Conley areas were obtained from the files of the West Virginia Department of Environmental Protection (Peter Costello, written commun., 2000), including borehole geophysical logs and water-level data for the U.S. Army Reserve Center, and borehole logs and water levels for the manufacturing facility.

\section{Boundary Conditions and Layers}

Boundary conditions for the Point Pleasant model were different than for any of the other models presented in this report. In the Point Pleasant area some alluvial sediments were deposited in an old meander cutoff (oxbow) of the Ohio River. This oxbow has not been documented in the past, but borehole records indicate two sequences of sand and gravel separated by an intermediate layer of silt and clay. The Point Pleasant model was therefore designed as a three-layer model to simulate the effects of the intermediate silt and clay layer in the old meander cutoff. Layer 3 represents the sand and gravel alluvial aquifer from an elevation of 475 to $510 \mathrm{ft}$ (fig. 3). Layer 2 extends from 510 to $570 \mathrm{ft}$ and represents the intermediate silt and clay layer (also shown on fig. 3). The uppermost layer (layer 1) extends from $570 \mathrm{ft}$ to land surface and represents the uppermost sand and gravel layer (fig. 4). Layer 2 essentially is not present in the area occupied by the alluvial aquifer adjacent to the Ohio River. The layers slope to higher elevations in the eastern part of the model to represent thinning of the alluvium in upland areas.

Generally, the area adjacent to the river is characterized by a fairly homogenous layer of sand and gravel. The northern part of the sand and gravel alluvial aquifer is less permeable than the southern part. It is likely that the knob of bedrock in the area to the north of the alluvial aquifer prevented the accumulation of large deposits of the more permeable sands and gravel whereas the southern part of the aquifer was exposed to reworking of sediments by the force of the Ohio River. As a result, a hydraulic conductivity of $83 \mathrm{ft} / \mathrm{d}$ was assigned to the northern part of the alluvial aquifer and a value of $350 \mathrm{ft} / \mathrm{d}$ was assigned to the southern part of the alluvial aquifer. The composition of sediments in the old meander cutoff is similar to that in the northern part of the alluvial aquifer and was assigned hydraulic conductivities ( 77 to $87 \mathrm{ft} / \mathrm{d}$ ) similar to that for the northern part of the alluvial aquifer. The intermediate silt and clay layer was assigned a hydraulic conductivity of $0.1 \mathrm{ft} / \mathrm{d}$.

The model consists of 59 rows and 28 columns and includes 1,652 cells (fig. 4). Approximately one third of the cells represent areas with bedrock outcrops and are inactive cells in the model. The model encompasses an area of 19,087 by $23,585 \mathrm{ft}$ or approximately 16.1 square miles $\left(\mathrm{mi}^{2}\right)$. The major boundary conditions of the model consist of river cells along the Ohio River and tributary streams and inactive cells in areas where bedrock crops out. A variably spaced model grid was used with a finer density of cells in the areas of the model near active pumping wells and a coarser grid in areas of the model of less relevance. As in the other models, simulation of groundwater seepage from adjacent bedrock aquifers was considered unnecessary. Oldtown Creek is the only major tributary in the model area. Discharge measurements were made on Oldtown Creek at two locations, one in the headwaters of the basin and a second near the bridge on route 62 . There was no appreciable increase or decrease in flow across the alluvial flat, indicating little interaction of the stream with the underlying alluvial aquifer.

Because there was no overlying confining unit, recharge to the alluvium in the Point Pleasant area was greater than that for either the Lubeck/Washington Bottom or Parkersburg/Vienna areas. For the model, recharge was set at $12 \mathrm{in} / \mathrm{yr}$ in the alluvial aquifer bordering the Ohio River and $11 \mathrm{in} / \mathrm{yr}$ in the area occupied by the old meander cutoff (fig. 5). Attempts to lower recharge rates below $11 \mathrm{in} / \mathrm{yr}$ were unsuccessful because the model could not calibrate to known heads with lower recharge rates.

\section{Model Calibration and Limitations}

The model of ground-water flow for Point Pleasant was calibrated by matching measured and simulated water levels. Of the four areas described in this report, the Point Pleasant area had the largest set of aquifer-characteristic data for model development and calibration. A total of 23 wells provided water-level data for model calibration. Model calibration goals were to match simulated to observed heads within $15 \%$ of the overall range in water level within the aquifer (about + or -4.2 feet). This is considered acceptable as water-level data was not collected as part of this investigation and the model is based entirely on existing data. Of the 23 wells used for model calibra- 


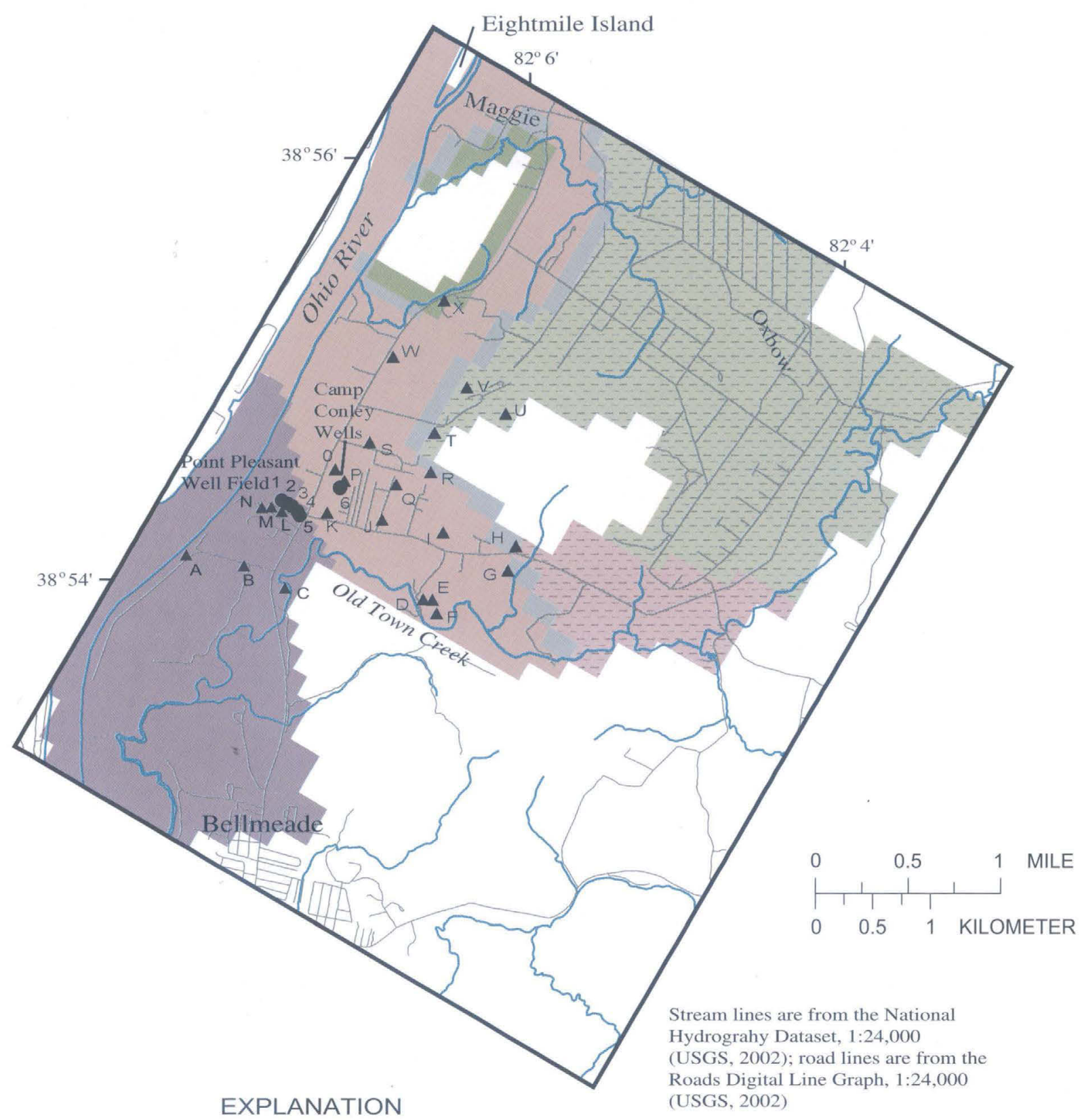

Model boundary

Bedrock (inactive cell area)

Wells

A Head observation

${ }_{1}$ - Production

- Streams

- Roads
Hydraulic conductivity of layer 2, in feet per day

0.1

Hydraulic conductivity of layer 3 , in feet per day

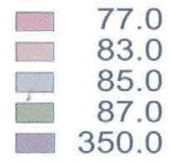

Figure 3. Values of hydraulic conductivity, inactive cells, and location of production and head observation wells in layers two and three of the Point Pleasant model. 


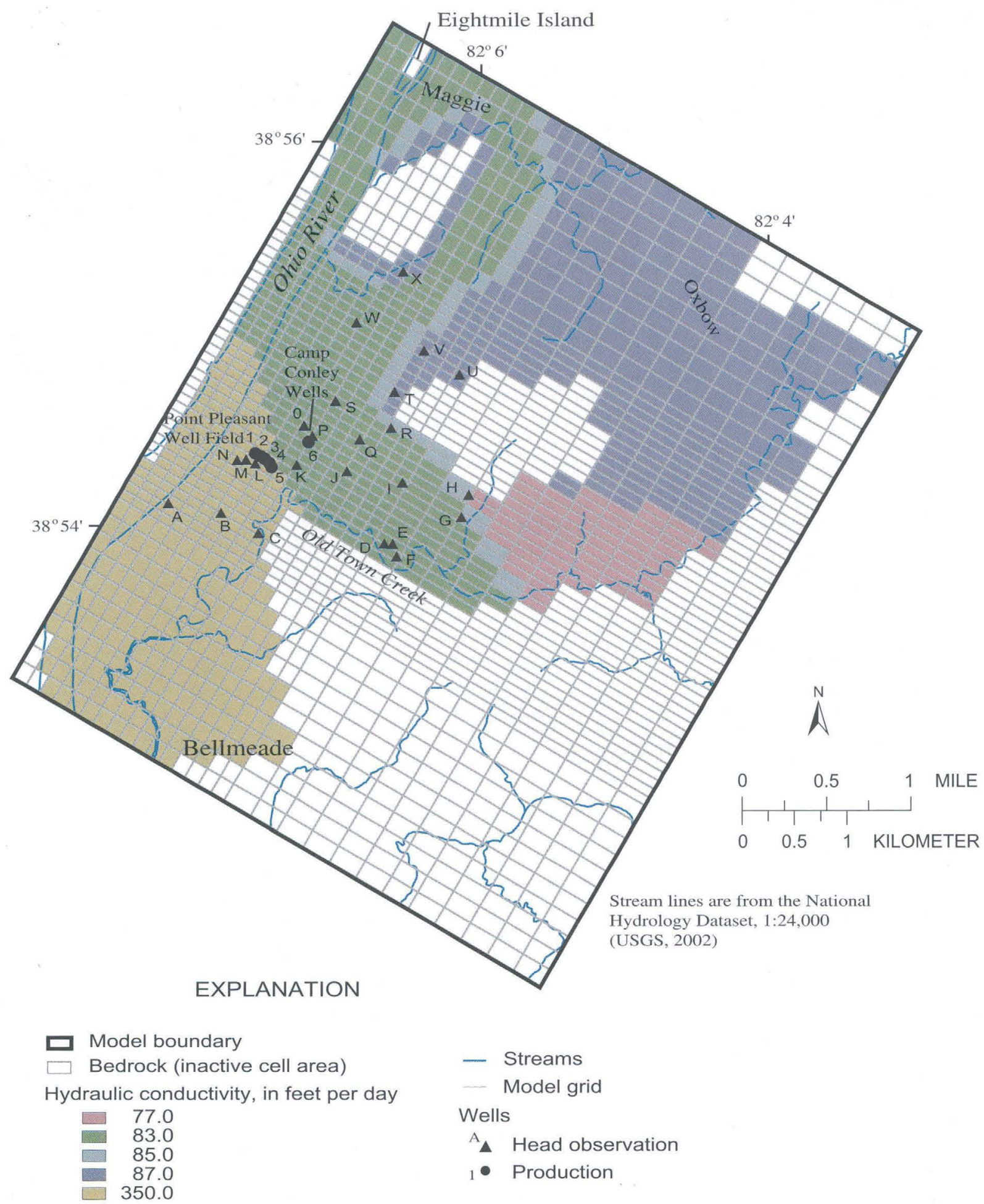

Figure 4. Values of hydraulic conductivity, model grid, inactive cells, and location of production and head observation wells in the upper layer of the Point Pleasant model. 


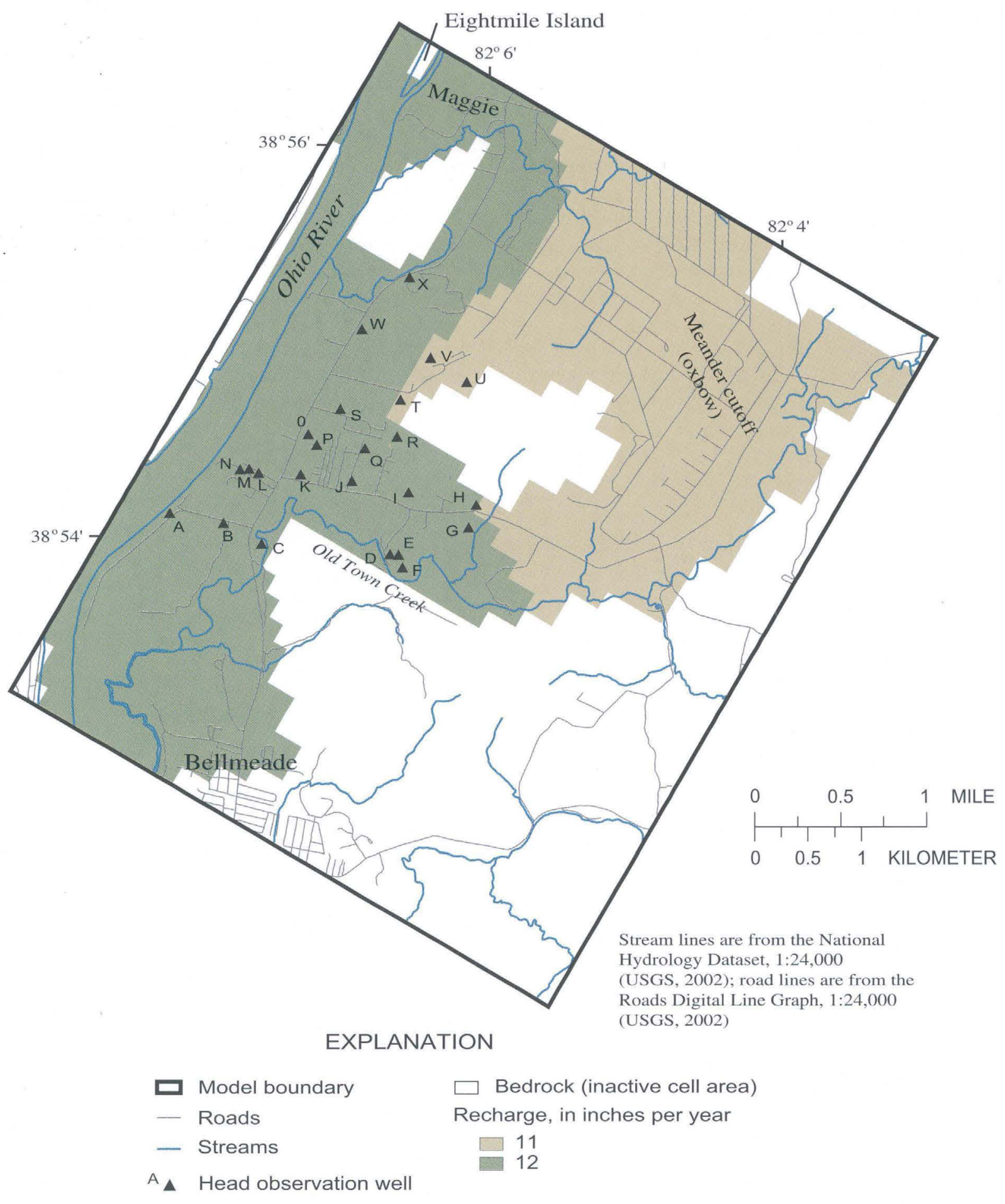

Figure 5. Head observation wells and recharge assigned to the upper layer of the Point Pleasant model. 
tion, only 3 failed to meet the $4.2 \mathrm{ft}$ error criteria and most wells calibrated to within a few feet of observed water levels. The calibrated model had a mean error of $-1.41 \mathrm{ft}$ and a root meansquared error of $3.80 \mathrm{ft}$. Most of the error was from wells in and near areas where the hydraulic conductivity changes significantly over short distances. In these areas, it is difficult to match simulated water levels to observed water levels. Fortunately, these areas are not adjacent to the active public supply wells, and the errors do not significantly affect the simulation of ground-water flow to the major pumping centers. Overall the model calibrated well and compared favorably to a potentiometric surface map prepared for the area in support of contamination investigations in the area (IT Corporation, 1996).

Potential limitations that could affect the accuracy of the simulation are mostly related to a lack of data in the uppermost regions of the potential recharge area to the public supply wells. Fortunately, data were sufficient to characterize the areas near the public supply wells. Additional data, especially borehole logs and water levels, would be needed to better refine the hydrogeology in the easternmost area of the model.

\section{Model Analysis and Interpretation}

Other than a few domestic wells that pump minimal quantities of water, the major ground-water withdrawals in the Point Pleasant well field and surrounding area are from the city of Point Pleasant well field and the wells at the Camp Conley PSD (fig. 6). Simulated flow paths indicate that none of the water pumped from the Camp Conley wells originates from the Ohio River. The 5-year time-of-travel area is less than $0.25 \mathrm{mi}$ in length, and derives most of its recharge from an area primarily to the east of the wellfield. The Point Pleasant and Camp Conley well fields derive water from the same general area and a change in the pumping schedule of one would likely cause a change in the flow paths and time of travel to the others. The degree of the change would be proportional to the rate of change in pumping.

Results of the simulations conducted for the Point Pleasant well field indicate that only a minimal amount of water, approximately 4 percent, is derived from river bed infiltration of water from the Ohio River. Most water (96 percent) is derived from a large circular area approximately $5,000 \mathrm{ft}$ by $4,700 \mathrm{ft}$ that surrounds the Point Pleasant well field. The 5-year time-of-travel area is approximately $0.84 \mathrm{mi}^{2}$. The contaminated land to the south is in the cone of depression surrounding the Point Pleasant well field and some wells on the southern side of the Point Pleasant well field have tested positive for trace amounts of contaminants.

\section{LubeckWashington Bottom Area}

The study area for the Lubeck/Washington Bottom ground-water-flow model extends from Ohio River mi 195 near Meldahl to Ohio River mi 190 to the north and incorporates part of Blennerhasset Island (fig. 7). The model area includes the Lubeck well field and two chemical manufacturing plants in
Washington Bottom. The modeled area is very large (approximately $23 \mathrm{mi}^{2}$ ) and was designed to be much larger than the expected recharge area to the Lubeck well field.

The model area was extended to these limits for two reasons. First, a surfactant, commonly known as $\mathrm{C} 8$ has been used in production processes at the chemical plant (chemical plant \#1) in the northern portion of Washington Bottom for a number of years, and some C-8 was released into the Ohio River and to the atmosphere as part of normal plant operations. Several wells in the Little Hocking well field showed traces of C-8 contamination; this led to an investigation to determine the extent and severity of the potential contamination. A ground-water-flow model was prepared to assess potential movement of C-8 from the plant area (Corporate Remediation Group, 2003). The high density of data available for the areas encompassing chemical plant \#1 and another nearby chemical manufacturing facility (chemical plant \#2) provided a clear boundary condition for the model and extensive data for model development and calibration.

In addition to the data collected for the C-8 investigation, a wealth of data was available from prior studies: (1) hydrogeologic investigations at the two chemical plants in Washington Bottom (Michael P. Sherrier - URS Corporation, written commun., 2001 and Peter Costello, W.Va. Department of Environmental Protection, written commun, 2000); (2) a wellhead protection area report for the Little Hocking, Ohio well field (Burgess and Niple, 1996); (3) hydrogeologic evaluations for additional water supply from Blennerhasset Island (Burgess and Niple, 1988; Leggette, Brashears, and Graham, 1986); and (4) investigations of bedrock geology for a part of the corridor $\mathrm{D}$ highway project and bridge crossing Blennerhasset Island just south of Parkersburg and at the north end of Washington Bottom (Ronald L. Adams, H.C. Nutting, written commun., 2002). Well records also were obtained for the Lubeck PSD (James Cox, Lubeck PSD, written commun. 2001).

\section{Boundary Conditions and Layers}

Boundary conditions for the Lubeck/Washington Bottom model are complex and have several constraints. The stratigraphy of the alluvium in the Lubeck area is complex; however, sediments can generally be categorized as glaciofluvial deposits of sands and gravels overlain by finer-grained fluvial deposits of silt and clay, many of which were deposited during floods (Carlston and Graeff, 1956). As such, the model design for the Lubeck area is composed of only two layers, a lower layer (fig. 8 ) representing more permeable sand and gravel deposits and an upper layer (fig. 9) representing finer grained silt and clay deposits. The model consists of 95 rows and 101 columns and includes 9,595 cells (fig. 8) and encompasses approximately 23 $\mathrm{mi}^{2}$. Due to the sinuous shape of the study area, nearly half of the cells in the model are inactive cells (fig. 9) and the model actually only simulates ground-water flow over an area of approximately $12 \mathrm{mi}^{2}$.

There is a great deal of variability in the hydraulic conductivity, especially in the upper silt and clay layer (table 2). 


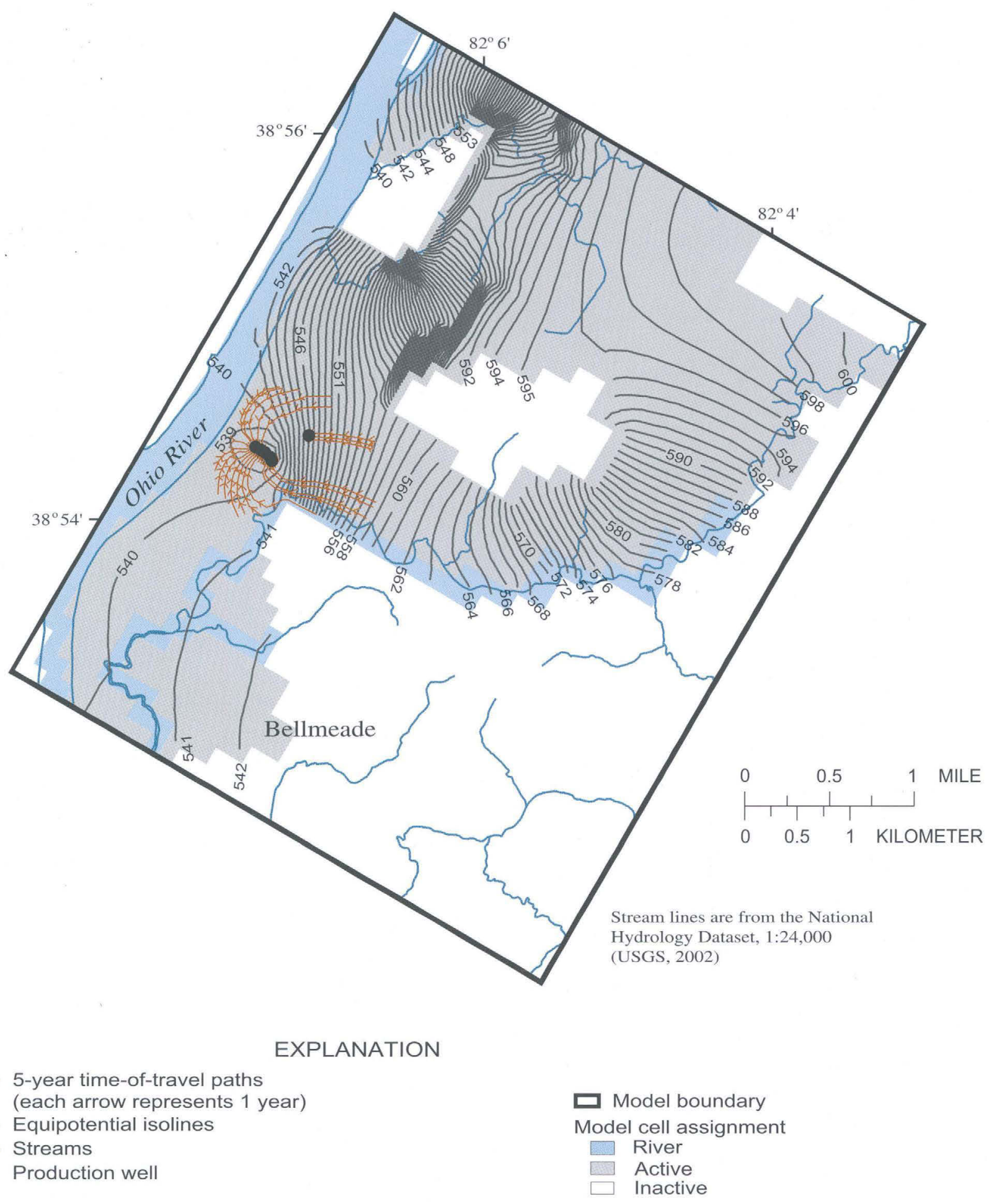

Figure 6. Calibrated heads and 5-year time-of-travel paths to the Point Pleasant well field in the lower layer (layer 3 ) of the model. 


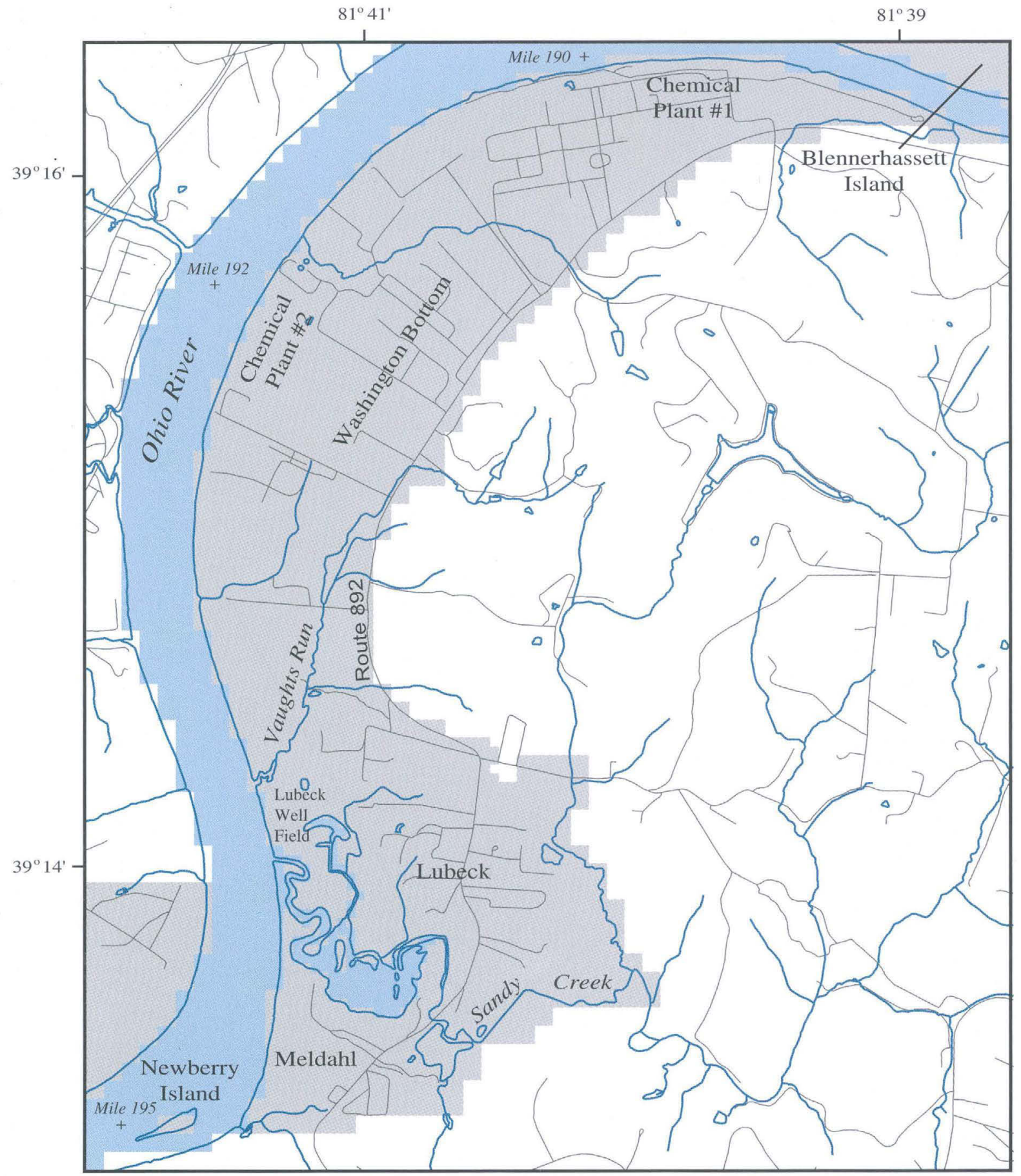

Stream lines are from the National Hydrography Dataset, 1:24,000 (USGS, 2002; road lines are from the Roads Digital Line Graph, 1:24,000 (USGS, 2002)

\section{EXPLANATION}

Model node assignment

River
Active
Inactive $\square$ Model boundary

- Roads

- Streams

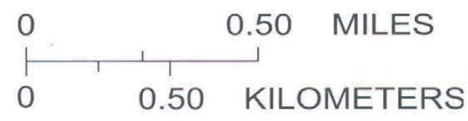

Figure 7. Location of the Lubeck/Washington Bottom model area, West Virginia (refer to figure 1 for general location map). 


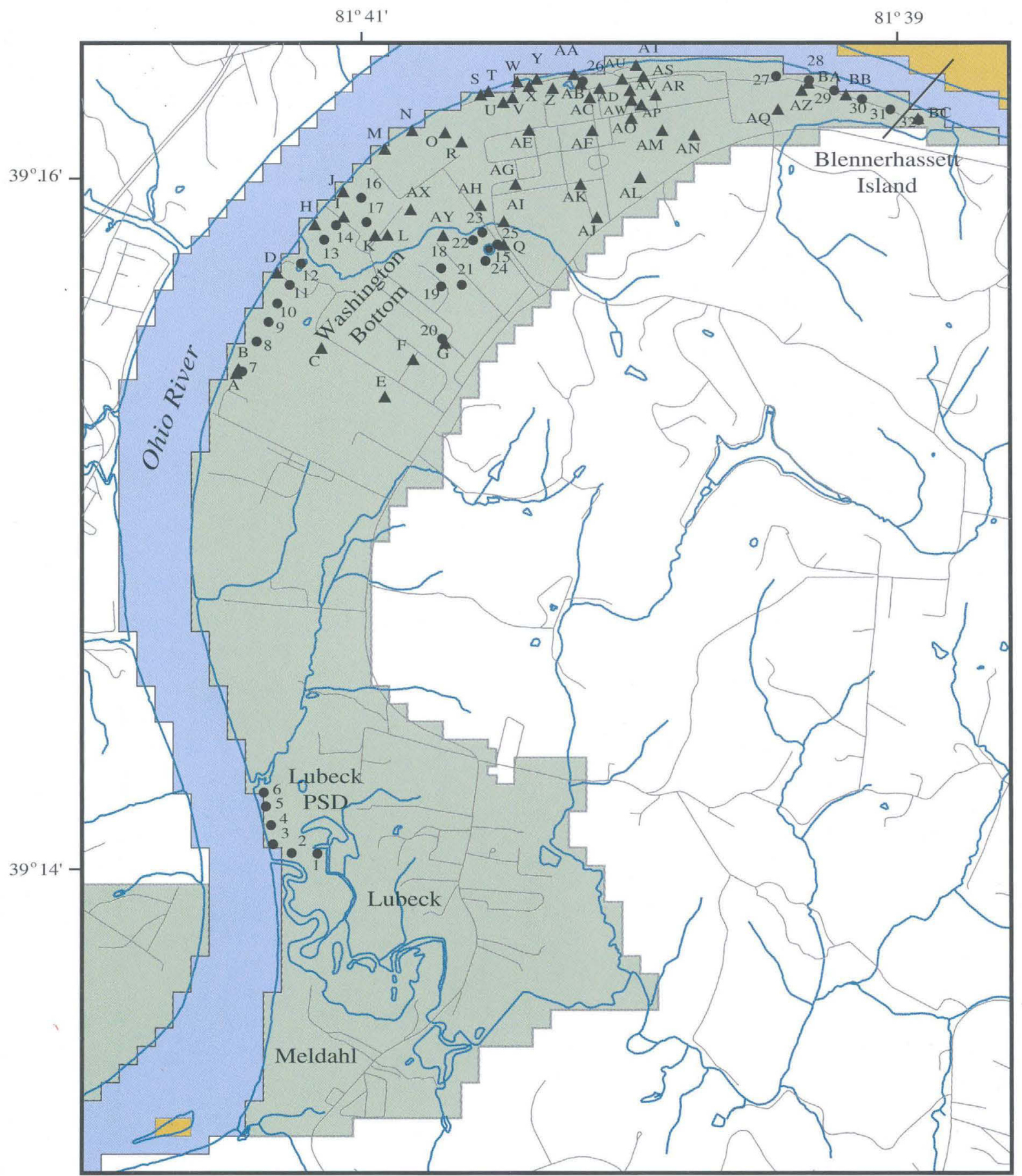

Stream lines are from the National Hydrology Dataset, 1:24,000 (USGS, 2002); road lines are from the Roads Digital Line Graph, 1:24,000 (USGS, 2002).

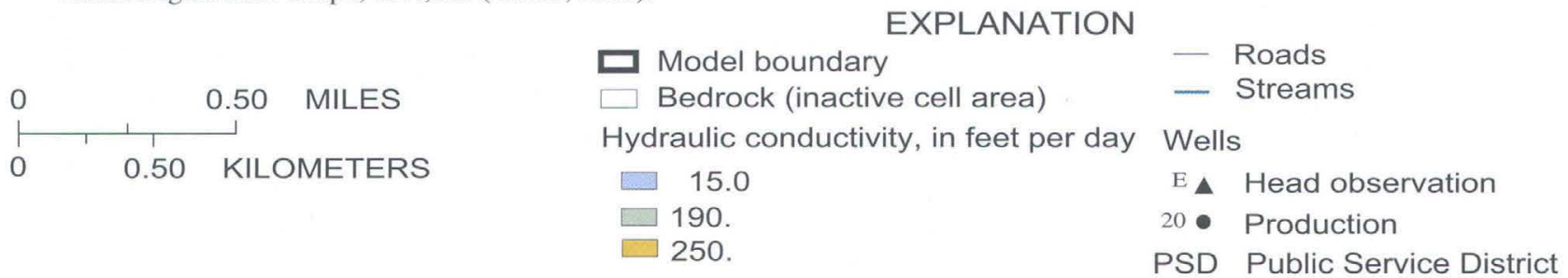

Figure 8. Values of hydraulic conductivity and location of production and head observation wells in the lower layer of the Lubeck/Washington Bottom model. 


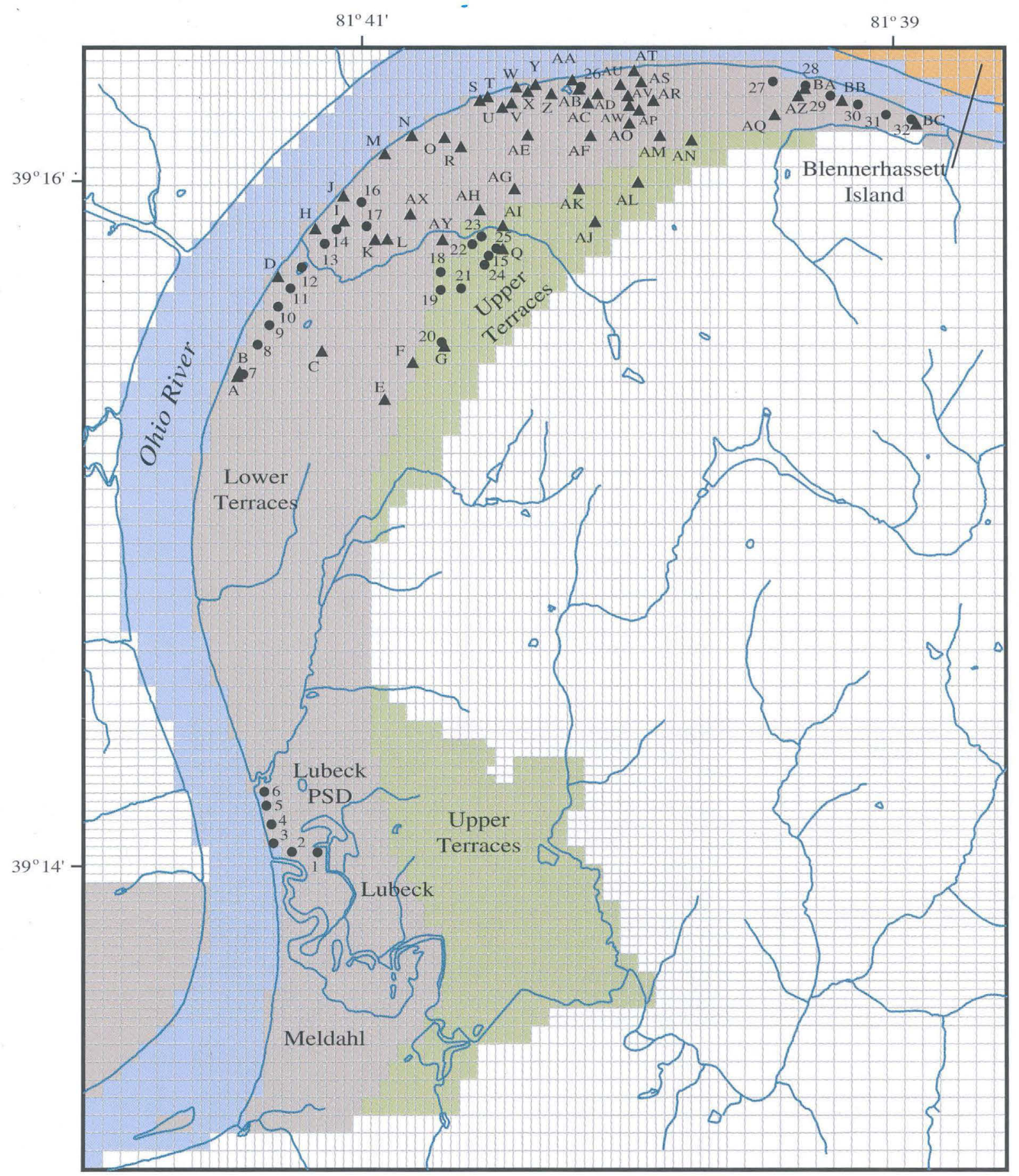

Stream lines are from the National Hydrography Dataset, 1:24,000 (USGS, 2002) .

EXPLANATION

Hydraulic conductivity, in feet per day

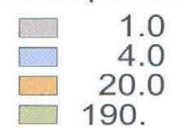

Model boundary

PSD Public Service District $\square$ Bedrock (inactive cell area)

- Streams Model grid

Wells

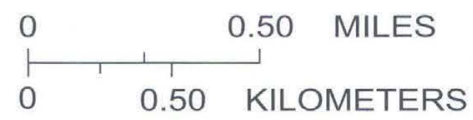

A Head observation

- Production

Figure 9. Well locations, model grid, inactive cells, and values of hydraulic conductivity in the upper layer of the Lubeck/Washington Bottom model. 
Hydraulic conductivity based on prior published estimates is complex for the model area. Generally, the lower alluvial aquifer was simulated from an elevation of 530 to $570 \mathrm{ft}$ and assigned a hydraulic conductivity of $190 \mathrm{ft} / \mathrm{d}$. The upper confining layer representing fluvially deposited silts and clays was simulated from $570 \mathrm{ft}$ to land surface and assigned a hydraulic conductivity of $1.0 \mathrm{ft} / \mathrm{d}$. The uppermost terraces are composed primarily of permeable sands and colluvium and assigned a hydraulic conductivity of $190 \mathrm{ft} / \mathrm{d}$, similar to that for the deeper aquifer.

Only alluvial sediments were included in the modeled area, and surrounding bedrock areas were not incorporated. This approach is valid because of the extreme variability in hydraulic conductivity for alluvial aquifers in the area compared to bedrock aquifers. The transmissivity of alluvial aquifers in the area ranged from 2,100 to $59,000 \mathrm{ft}^{2} / \mathrm{d}$ with a mean of 9,400 $\mathrm{ft}^{2} / \mathrm{d}$ (Kozar and Mathes, 2001). Bedrock aquifers in the area have transmissivities averaging only about $130 \mathrm{ft}^{2} / \mathrm{d}$ (Kozar and Mathes, 2001). Thus, the low transmissivity of bedrock aquifers would result in negligible inflow of ground water to the alluvial aquifer from bedrock.

Results of the ground-water-flow model for this study were compared with the previous model developed for the Lubeck area that incorporated bedrock areas (Corporate Remediation Group, 2003), and no discernible difference between the models was found. This comparison indicates that simulation of ground-water flow in Ohio River alluvial sediments does not require inclusion of flow from bedrock areas and also indicates that ground-water flow to the alluvium from bedrock is minimal.

River cells and no-flow cells were the two primary boundary conditions used in the design of the Lubeck model. The Ohio River was simulated with a series of river cells and included a large backwater wetland area near the Lubeck well field. No-flow cells were set at the margin between the bedrock and the alluvium. During the course of this study (January 2001 to December 2003), the modeled areas experienced severe drought. As a result, no flow was visible in any of the tributary streams flowing from bedrock onto the alluvium. Seepage measurements could not be made to assess the effect of groundwater seepage to or from these tributaries. Discharge measurements made in the Parkersburg/Vienna and Point Pleasant areas as part of this investigation (to be discussed later in this report) did not indicate appreciable flow either from or to the tributary streams, and the minimal seepage from the streams would have had a negligible effect on the overall water budget even if present. The few tributary streams in the area were therefore not specifically included in the model using either river or drain cells. If flow had been present in the streams, it is likely that only a minor component could have infiltrated to the underlying alluvial aquifer.

Recharge was assigned to the upper layer (fig. 10) on the basis of the relative permeability of sediments at the surface. The area occupied by the lower terraces was assigned a recharge of $7 \mathrm{in} / \mathrm{yr}$ and the colluvial deposits in the area were assigned a recharge of $9.8 \mathrm{in} / \mathrm{yr}$. Alluvial sediments on Blennerhasset
Island generally were more permeable and were assigned a recharge of $11 \mathrm{in} / \mathrm{yr}$.

\section{Model Calibration and Limitations}

One major modification to the model was necessary to provide an accurate simulation of ground-water flow in the area. An influx of fine-grained sediments deposited by large volumes of water from the Little Kanawha River into the Ohio River has apparently resulted in significant reworking of the sediments in the Ohio River immediately downstream of the confluence with the Little Kanawha River. Thus, the hydraulic conductivity of sediments in the Ohio River immediately downstream from the Little Kanawha River is likely to be much lower than the hydraulic conductivity of river sediments near Parkersburg and Vienna. A previous ground-water-flow model developed to document potential transport of C-8 in the Washington Bottom area (Corporate Remediation Group, 2003) encountered this situation and resolved the problem by adjusting the conductivity of river-bottom sediments.

The ground-water-flow model was calibrated by matching simulated and measured water levels. A total of 76 wells provided water-level data for model calibration. Model calibration goals were to match simulated to observed heads within $15 \%$ of the overall range in water level within the aquifer (about + or 4.5 feet). This is considered acceptable as water level data was not collected as part of this investigation and the model is based entirely on existing data. Of the wells used for model calibration, only 9 of the 76 wells failed to meet the $4.2 \mathrm{ft}$ error criteria and most wells calibrated to within a few feet of observed water levels. The calibrated model had a mean error of $1.59 \mathrm{ft}$ and a root mean squared error of $3.24 \mathrm{ft}$. Most of the error is due to wells being situated near pumping centers. In these areas, computed water levels in pumping cells reflect the average water level in the cell. The simulated heads of monitoring wells in these cells were slightly higher than those actually observed.

Numerous limitations could affect the accuracy of this simulation. The major limitation is lack of detailed information on the composition of the alluvium near the Lubeck well field. Although substantial data are available from past investigations in Washington Bottom, little data relates to aquifer properties for the area immediately adjacent to the Lubeck well field. In addition, reworking of sediments in the Ohio River downstream from the confluence with the Little Kanawha River has resulted in significant alteration of the hydraulic properties of sediments in the streambed. Unfortunately, the exact nature and properties of the reworked sediments are not known. Finally, the geometry of the alluvial aquifer is poorly understood in the area near the Lubeck well field.

\section{Model Analysis and Interpretation}

Results of modeling in the Washington Bottom and the Lubeck well field indicate that the primary source of flow to the Lubeck well field is not derived from the immediate area occupied by the nearby chemical plants (fig. 11). Most flow is derived from the area immediately adjacent to the Lubeck well 


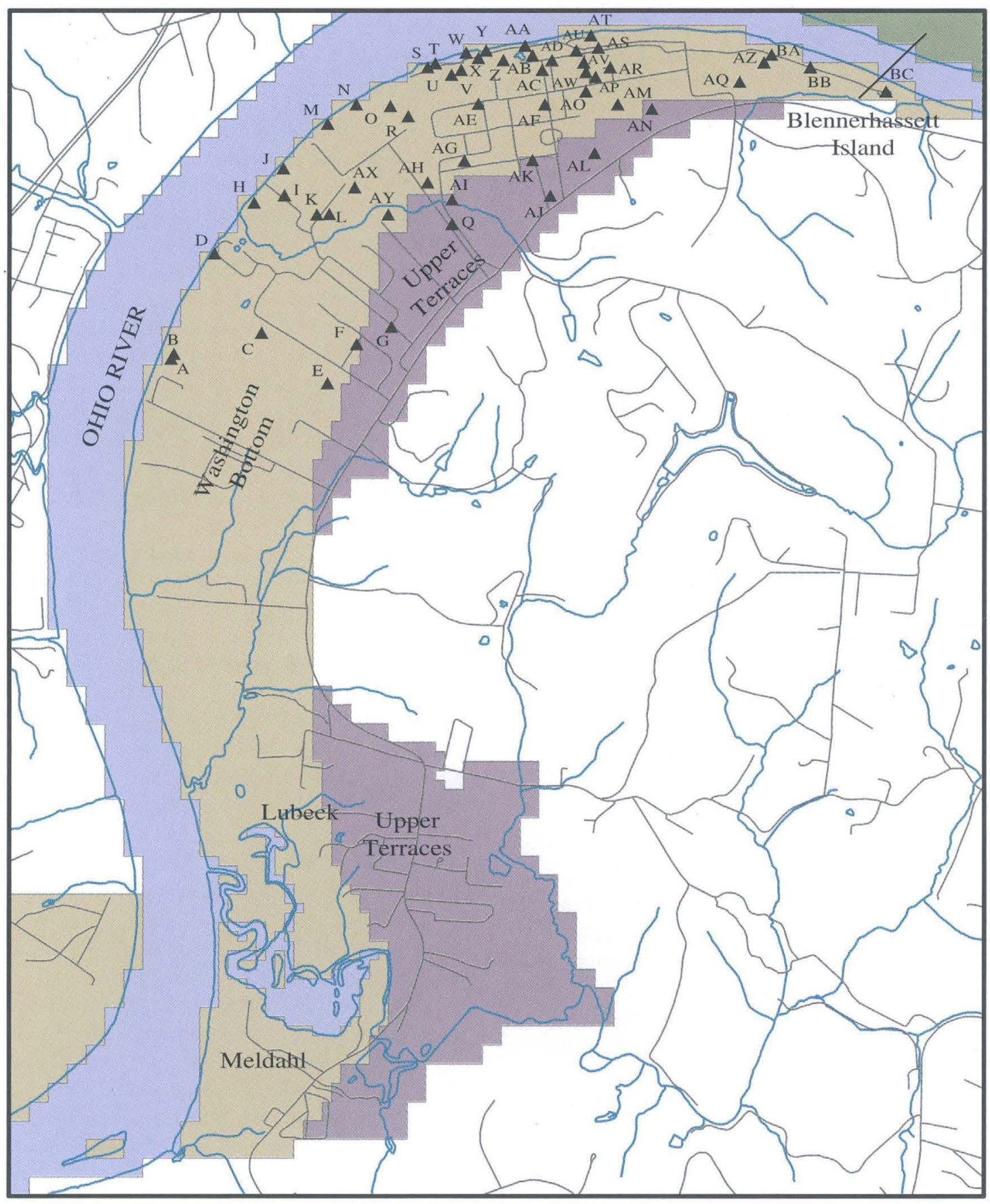

Stream lines are from the National Hydrology Dataset, 1:24,000 (USGS, 2002); road lines are from the Roads Digital Line Graph, 1:24,000 (USGS, 2002).

\section{EXPLANATION}
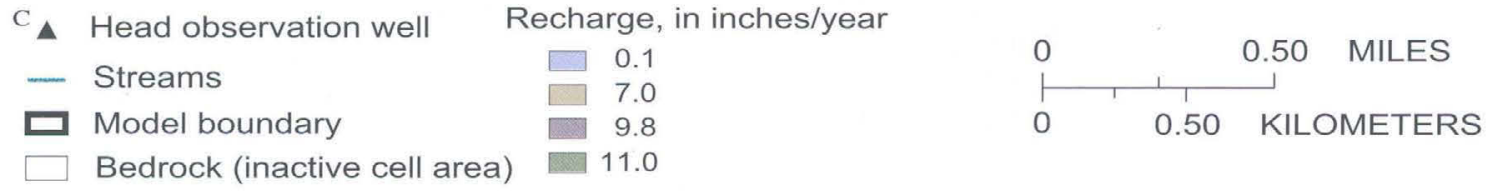

Figure 10. Head observation wells and recharge assigned to the upper layer of the Lubeck/Washington Bottom model. 


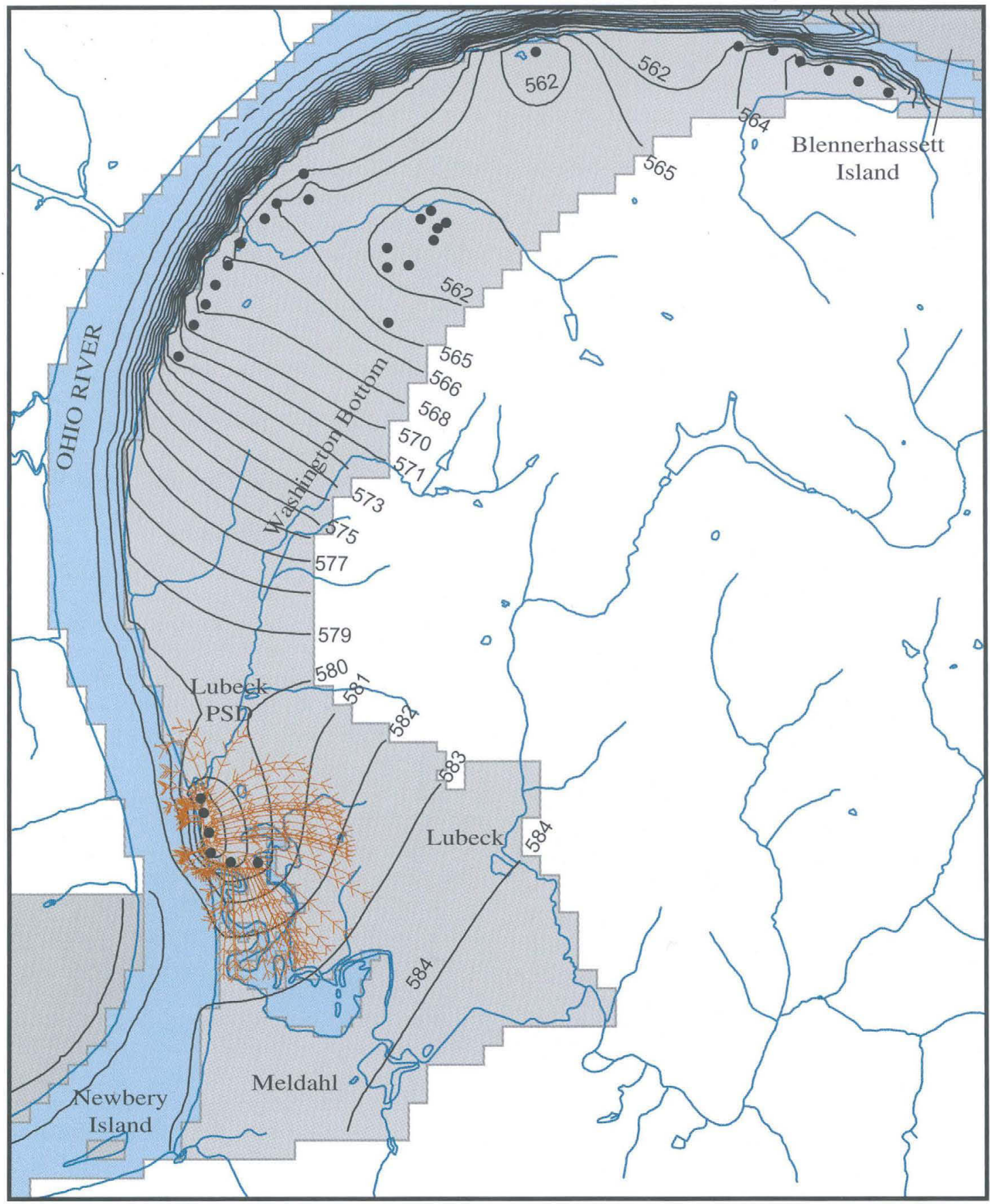

Stream lines are from the National

Hydrology Dataset, 1:24,000

(USGS, 2002)

- 5-year time-of-travel paths (each arrow represents 1 year)

- Equipotential isoline

- Streams

- Production well

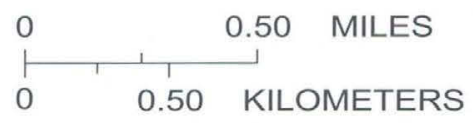

EXPLANATION

$\square$ Model boundary Model cell assignment

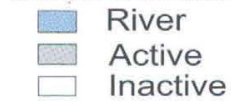

PSD Public Service District

Figure 11. Calibrated heads and 5-year time-of-travel paths to the Lubeck well field in the lower layer of the Lubeck/Washington Bottom model. 


\section{Ground-Water Flow in Selected Ohio River Alluvial Aquifers, West Virginia}

field near Vaughts Run and Sandy Creek. Part of the flow to the Lubeck well field also is derived directly from the Ohio River, which could be a source of contaminants. Hydraulic gradients indicate that the water table near the Lubeck well field is actually at a higher elevation than the water table near the chemical plants. The Lubeck well field probably does not receive recharge from the northern part of the Washington Bottom area. Of approximately 665,000 gal of water pumped daily from the Lubeck well field, about 261,600 gal (39 percent) is derived from induced infiltration from the Ohio River and about $403,400 \mathrm{gal}$ (61 percent) is derived from the capture of ground water in the alluvium. The area over which recharge to the alluvium would occur in a 5-year period (5-year time of travel) is approximately $3,320 \mathrm{ft}$ by $4,338 \mathrm{ft}$ or $0.5 \mathrm{mi}^{2}$ (fig. 11).

\section{Parkersburg/Vienna Area}

The modeled area for the Parkersburg/Vienna model extends from the confluence of the Ohio and Little Kanawha Rivers near Ohio River mi 185 in Parkersburg to the upper end of the alluvial flat at the north end of Vienna near Ohio River mi 178 to the north (fig. 12). The modeled area includes the cities of Vienna and Parkersburg. Both cities are located on the same alluvial flat or river bottom and it was logical to simulate ground-water flow for both sites simultaneously.

Data for the Parkersburg/Vienna area are not as abundant as in the Lubeck/Washington Bottom area. A RCRA investigation was conducted and a ground-water-flow model (CDM, $2002 b$ ) was developed to assess the fate and transport of PCE from a long-term discharge at a dry-cleaning operation in Vienna. The RCRA investigation provided a substantial amount of hydrogeologic data (Aaron Frantz, CDM Federal Programs Corporation, written commun., 2001) from which a groundwater-flow model could be developed that encompassed the larger Parkersburg and Vienna area. Water-level measurements were made by USGS personnel in a series of old production wells in the Parkersburg well field; data collected was used for model calibration for the southern part of the model area. Data from the Lubeck/Washington Bottom area was very useful for design and calibration of the Parkersburg/Vienna model. Washington Bottom is less than $2 \mathrm{mi}$ south of the confluence of the Ohio and Little Kanawha Rivers and is hydrogeologically similar to the Parkersburg/Vienna alluvial flat. Extrapolation of data from one site to the other helped model design and calibration for both models.

\section{Boundary Conditions and Layers}

The Parkersburg alluvial aquifer is adjacent and similar to the Lubeck/Washington Bottom area with one major exception. The Little Kanawha River flows into the Ohio River at the southern terminus of the Parkersburg/Vienna bottom. Finegrained sediments from the Little Kanawha River are deposited below but not above the confluence. Therefore, the alluvial sediments in the Parkersburg/Vienna bottom typically have a higher proportion of sand and gravel and a smaller proportion of silt and clay than river bottom deposits in the Lubeck/Washington Bottom area. The assigned hydraulic conductivity of Ohio River bottom sediments was therefore much higher (hydraulic conductivity of 175-300ft/d) for the Parkersburg/ Vienna area than for the Lubeck/Washington Bottom area (hydraulic conductivity of 4-15 ft/d). However, the alluvial sediments in the lower glacial outwash terrace deposits in the Parkersburg/Vienna area (hydraulic conductivity of $175-300 \mathrm{ft} / \mathrm{d}$ ) were not appreciably different from those of the Lubeck/Washington Bottom area (hydraulic conductivity of 190-250 ft/d).

The Parkersburg/Vienna model included two layers, a lower layer (fig. 13) representing glacial outwash sands and gravels and an upper layer (fig. 14) representing primarily fluvial silt and clay flood-plain deposits. The upper silt and clay confining layer was assigned hydraulic conductivities ranging from 1 to $3 \mathrm{ft} / \mathrm{d}$ and the lower layer was assigend hydraulic conductivities ranging from 100 to $300 \mathrm{ft} / \mathrm{d}$ (table 2). The upper confining unit is common in most of the alluvial terraces along the Ohio River (Carlston and Graeff, 1956). The lower alluvial aquifer was simulated from an elevation of approximately 540 to $600 \mathrm{ft}$ and the upper layer representing fluvial deposits was simulated from $600 \mathrm{ft}$ to land surface. The model consists of 69 rows and 30 columns and includes 2,070 cells (fig. 14). Approximately one-third of the cells represent areas with bedrock outcrops and are inactive in the model. The model encompasses an area of 16,605 by $35,705 \mathrm{ft}$ or approximately $21.3 \mathrm{mi}^{2}$.

The two primary boundary conditions used in model development included river cells and inactive cells. Bedrock aquifers have much lower permeabilities than alluvial aquifers and were therefore simulated as inactive cells (fig. 14). Because there was flow in tributary streams during development of the Parkersburg model, and because the effect of these streams on the overall hydrology of the area is unknown, river cells were used to simulate ground-water seepage to and from tributary streams. The interaction between tributary streams and the underlying alluvial aquifer were determined to be minimal.

Recharge for the Parkersburg model ranged from 3 to $9 \mathrm{in} /$ yr (fig. 15) and was assigned to layers according to the permeability of sediments in the terraces. The composition of alluvial sediments in the Vienna area was very different from that in the Parkersburg area. Because the overlying silt and clay deposits are much thicker in the Parkersburg area than in the Vienna area, recharge rates of 6 and 9 in/yr, were assigned to the Parkersburg and Vienna areas, respectively. The upper terraces in the Parkersburg area are characterized by much thinner accumulations of alluvial deposits, with a high percentage of silt and clay, and were assigned a recharge value of only $3 \mathrm{in} / \mathrm{yr}$.

\section{Model Calibration and Limitations}

The ground-water-flow model for the Parkersburg/Vienna area was calibrated by matching simulated and measured water levels. A total of 28 wells provided water-level data for model calibration. Model calibration goals were to match simulated to observed heads within $10 \%$ of the overall range in water level within the aquifer (about + or -4.0 feet). This is considered 


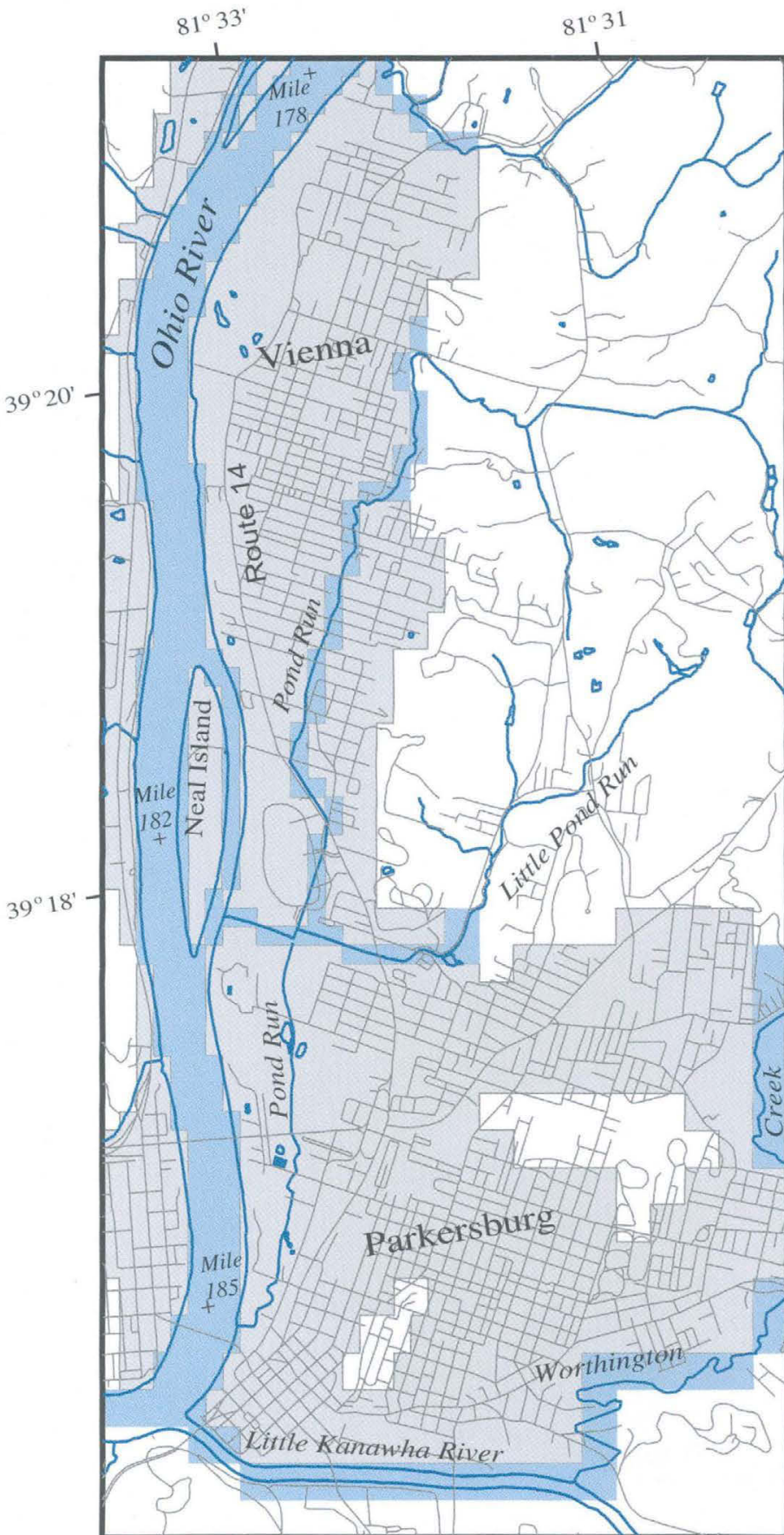

Stream lines are from the $\mathrm{Nat}$ Hydrology Dataset, $1: 24,000$ from the (USGS, 2002); road lines , 1:24,000 Roads Digital (USGS, 2002)

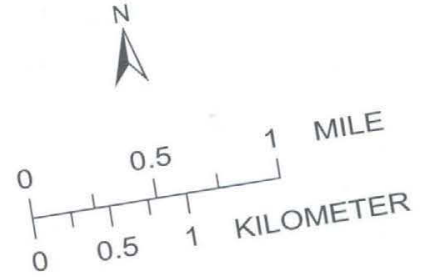

Model cell assignment River Active Inactive Model boundary 
Flow in Selected Ohio River Alluvial Aquifers, West Virginia

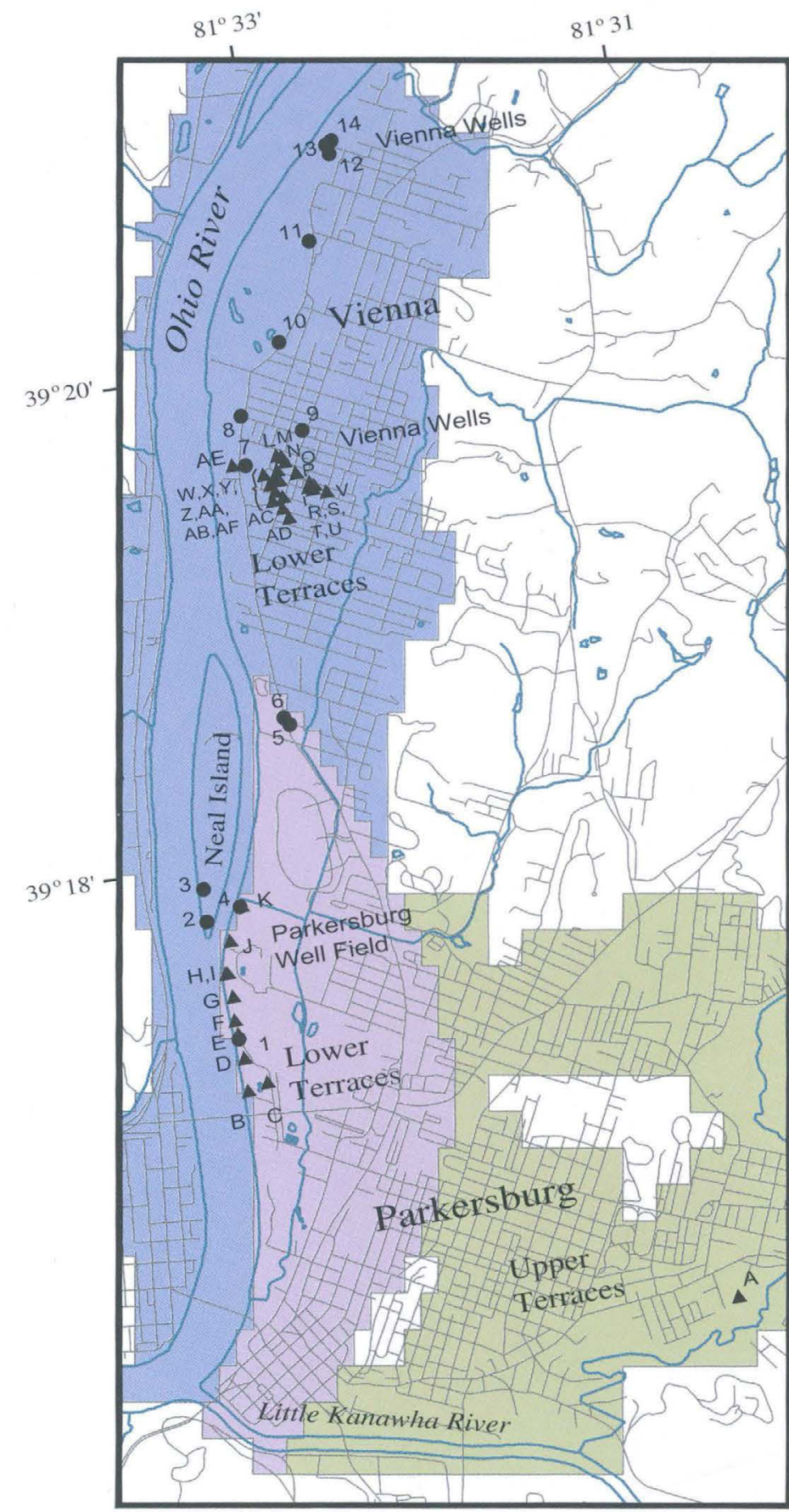

are from the Nationa

Stream lines are fret, 1:24,000 Hydrology 2002; road lines are $1: 24,000$ (USGS, 2002,

(USGS, 2002

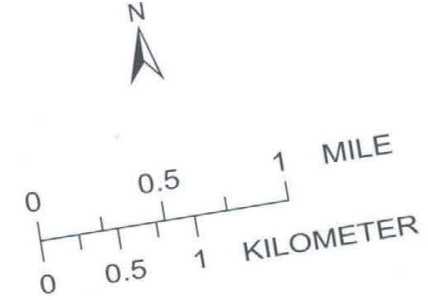

Model boundary

Bedrock (inactive cell feet per day

- Streams

Hydraulic con

Roads

$\square \quad 175$

Wells

A Head observation Figure 13. Values of hydraulic
Parkersburg/Vienna model.

civity and locations of produr

- 


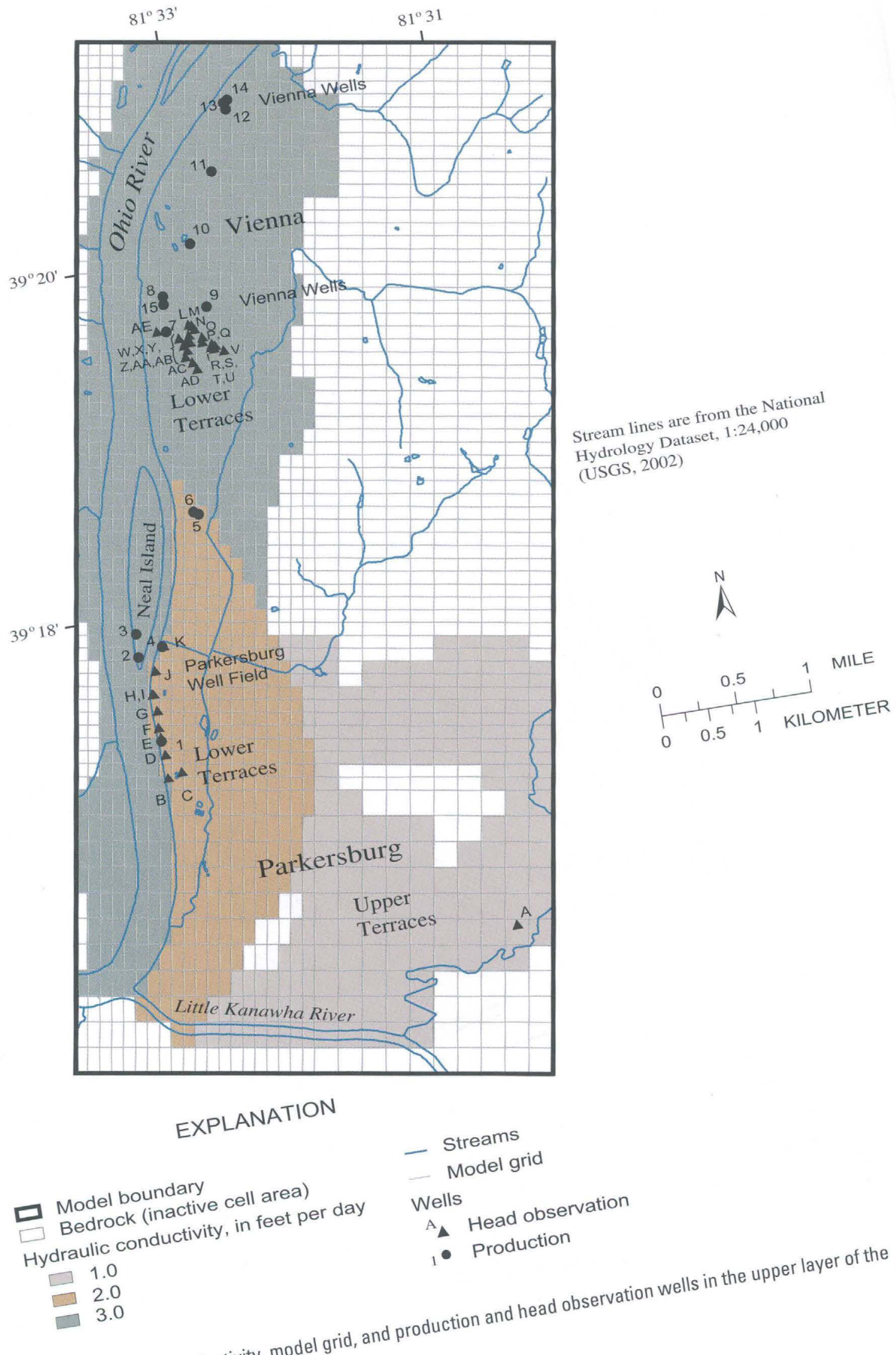

Figure 14. Values of hydraulic
Parkersburg/Vienna model. 
Ground-Water Flow in Selected Ohio River Alluvial Aquifers, West Virginia

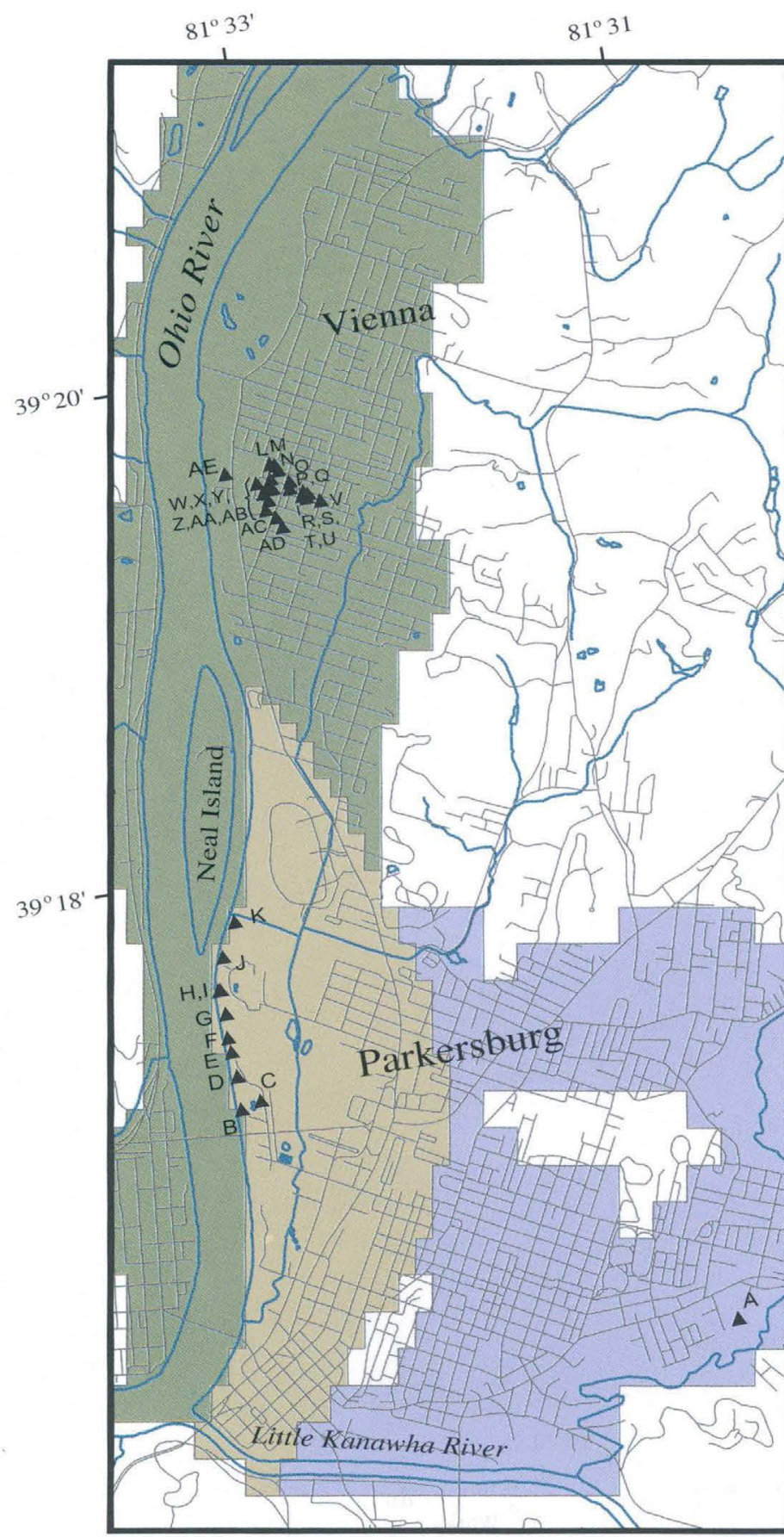

lines are from the National Stream Hydrology 002 ; road lines are 1:24,000 Roads Digital (USGS, 2002

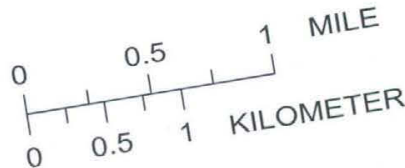

$\square$ Model boundary

- Roads

- Streams

A Head observation well $\square$ Bedrock in inches per year

$$
\square 3.0
$$

charge values assigned to the upper layer of the Parkersburg/Nienna model. 
acceptable as water-level data was only collected in the area near the Parkersburg well field as part of this investigation. The remainder of the model, especially for the Vienna area, is based entirely on existing data. Of the wells used for model calibration, only 4 of the 28 wells failed to meet the $4.0 \mathrm{ft}$ error criteria and most simulated water levels calibrated to within a few feet of observed water levels. The calibrated model had a mean error of $1.44 \mathrm{ft}$ and a root mean-squared error of $3.22 \mathrm{ft}$. Most of the error is from observation wells located near the River or near pumping centers with steep hydraulic gradients. Computed water levels in cells with pumping wells reflect the average water level in the entire cell whereas water levels of observation wells in these cells would be expected to have slightly higher simulated water levels because they generally would not be adjacent to the pumping wells. It is also difficult to match simulated and observed water levels in areas near river cells

The accuracy of the model simulation for the Parkersburg/ Vienna area is mostly related to the characterization of the geometry of the aquifer system. Hydrogeologic data are available for the alluvium at and adjacent to the Ohio River and the Parkersburg and Vienna well fields, but the area closer to the bedrock valley wall has less data and is not as well characterized. The resulting uncertainty of the geometry of the alluvial aquifer could result in errors in time-of-travel estimates made using particle-tracking software. Additional borehole logs would be needed to refine the aquifer geometry in the area near the bedrock valley walls and the uppermost river terraces.

\section{Model Analysis and Interpretation}

Ground-water flow in the alluvial aquifer near Parkersburg and Vienna is complicated and has been modified substantially by the cones of depressions from the major pumping wells in the area (fig. 16). This is especially true for the Parkersburg well field (fig. 16) where pumping of 4.78 million gallons of water per day $(\mathrm{Mgal} / \mathrm{d})$ has resulted in a cone of depression in the water table approximately $2 \mathrm{mi}$ long parallel to the Ohio River and $1 \mathrm{mi}$ wide.

Conversely, cones of depression around wells in the Vienna area are much smaller (fig. 16) because of two factors. The first factor is total withdrawals: wells in the Vienna area, including the municipal wells and wells at an industrial plant and nearby golf course, only withdraw an average of $1.58 \mathrm{Mgal} / \mathrm{d}$ compared to $4.78 \mathrm{Mgal} / \mathrm{d}$ for the Parkersburg plant. The second factor relates to well location: wells in the Vienna area are scattered over the entire alluvial flat from the southern end of Vienna to its northern terminus; wells in the Parkersburg well field are clustered in a tight group on the river bank and on Neal Island. There is a considerable difference in hydraulic gradients in the alluvium due to differences in the hydraulic properties of the two areas. The alluvial deposits in the Parkersburg area have a higher percentage of silt and clay than the alluvial deposits in the Vienna area. The confining unit in Parkersburg is substantially thicker than the confining unit in the Vienna area. As a result, withdrawal of ground water in the Parkersburg area produces larger cones of depression than those in the coarser-grained deposits in the Vienna area.

Wells in the Parkersburg well field derive the majority of their water by inducing infiltration from the Ohio River. Collector wells in the well field were designed and built for this purpose. Simulations indicate that approximately 75 percent of water pumped from the Parkersburg well field is derived from the river and only 25 percent is derived from capture of water in the alluvium. Because much of the water in the Parkersburg well field is derived from infiltration of water through the riverbed, estimated 5-year time-of-travel distances for wells are typically short and confined to areas in the riverbed and the area between the cones of depression in the well field itself. The 5 -year time-of travel-area is roughly $1.18 \mathrm{mi}^{2}$ in size.

Wells in the Vienna well field produce less drawdown but typically pull in water over a larger area than wells in the Parkersburg area due to the thinner confining unit in the Vienna area. Typical 5-year time-of-travel areas for wells in the Vienna area are 3,000 ft in diameter or approximately $0.25 \mathrm{mi}^{2}$. Groundwater budgets indicate that the Vienna public supply wells receive a much smaller percentage of riverbed recharge than wells in the Parkersburg well field. Of the average $1.4 \mathrm{Mgal} / \mathrm{d}$ of water pumped from public supply wells for the city of Vienna, only 7 percent is estimated to be derived from induced infiltration from the Ohio River. The majority (93 percent) is derived by capturing ground water which would have flowed through the alluvium to the river. Smaller private wells, such as wells at a local golf course, a small industrial plant, and a church had much smaller 5-year time-of-travel zones and associated cones of depression.

\section{Moundsville/Glendale}

The WVBPH has been mandated to develop WHPA delineations for all public water systems in the State of West Virginia. Many sites for which WHPA delineations are required lack substantive data for model development and calibration. Although there is a sparsity of data, these sites would still benefit from analysis using numerical ground-water-flow models. Successful model development for the Moundsville/Glendale area shows that it is possible to develop models for areas with limited data if there is a good conceptual understanding of ground-water flow in the aquifer. The Moundsville/ Glendale area was selected for model development to represent a worstcase scenario from a modeling standpoint. The Moundsville/ Glendale model was the last of the four models developed in this study so that data and conceptual understanding gained in developing and calibrating the models for the previous three model areas could be extrapolated. This approach resulted in a model, that although limited in calibration data, seems reasonable from a hydrogeologic perspective.

The model for the Moundsville/Glendale area extends from the mouth of Little Grave Creek in the town of Moundsville near Ohio River mile 101.5 north to Glendale Heights near Ohio River mile 98.0 (fig. 17). Of the four models presented in 
Ground-Water Flow in Selected Ohio River Alluvial Aquifers, West Virginia

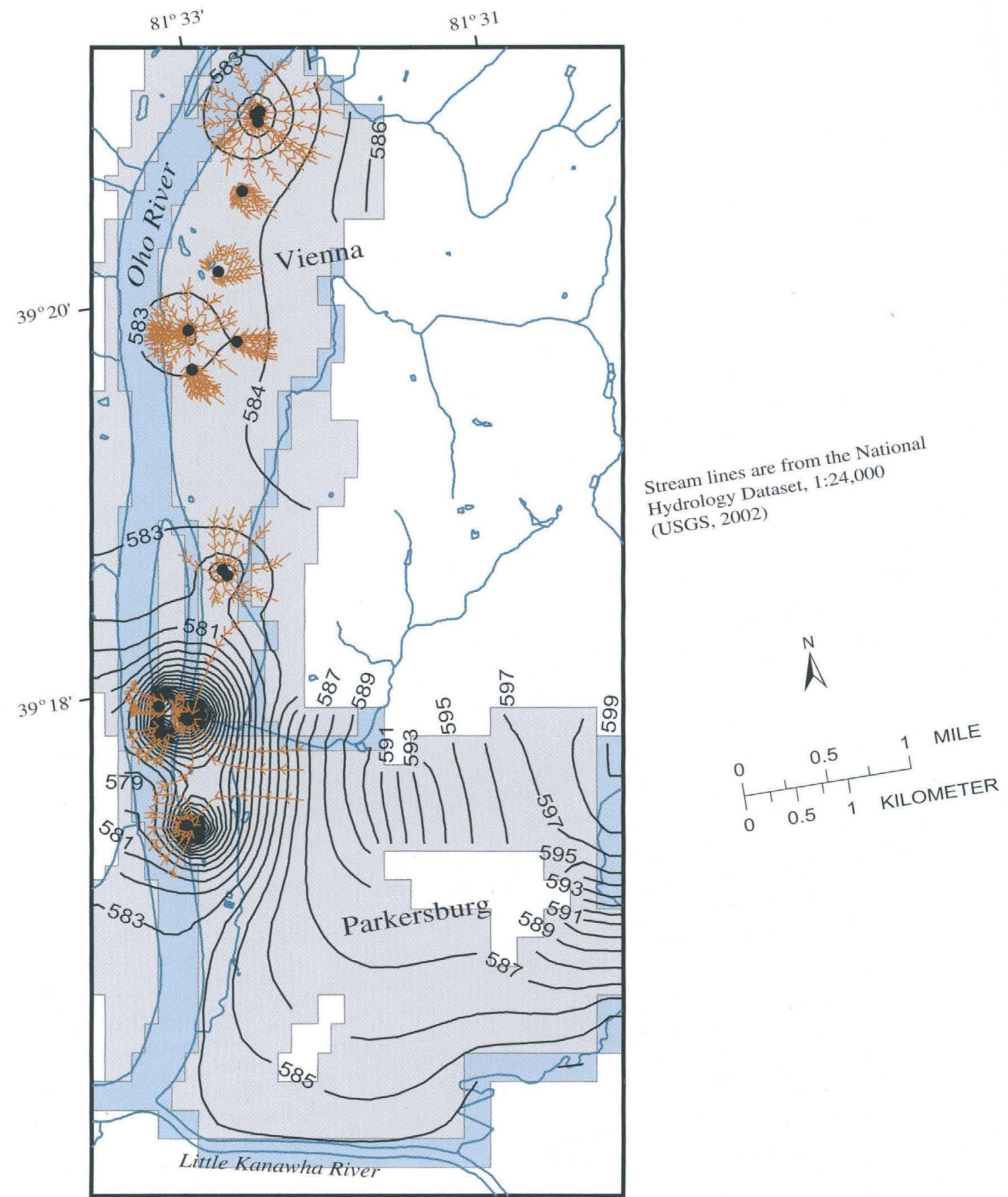

-year time-of-travel paths

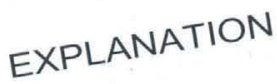

Model boundary

Model cell assignment

(each arrow represents 1 year)

River
Active
Inactive

- Equipotential isolines

- Streams

- Production wells

fravel paths to the Parkersburg and Vienna well fields in the lower layer of the model. 


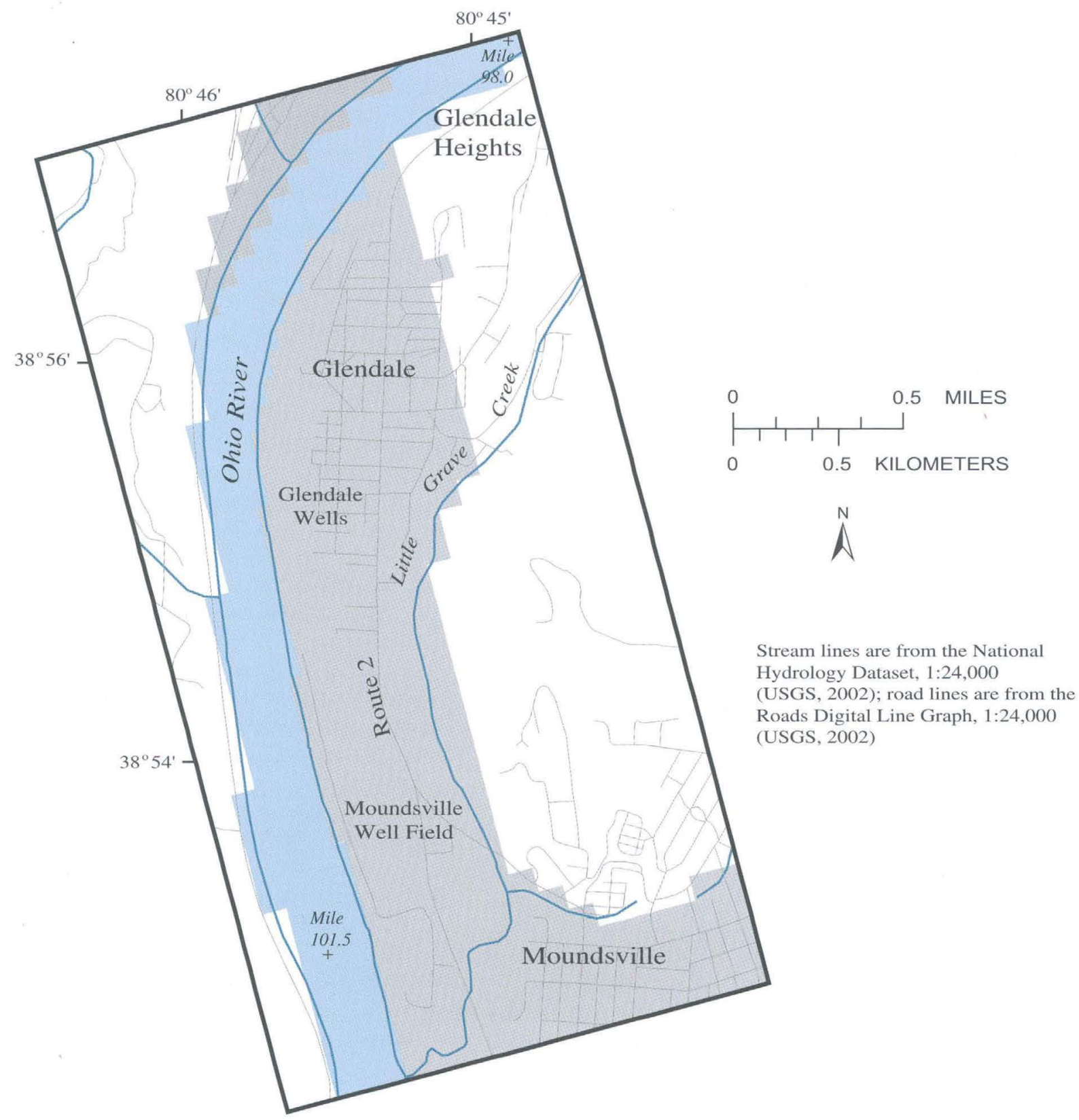

EXPLANATION

$\square$ Model boundary

- Roads

- Streams
Model cell assignment

River

Active

Inactive

Figure 17. Location of the Moundsville/Glendale model area, West Virginia (refer to figure 1 for general location map). 


\section{Ground-Water Flow in Selected Ohio River Alluvial Aquifers, West Virginia}

this report, the Moundsville/Glendale model covers the smallest area. Both the Moundsville and Glendale Water Plants and their respective well fields are close to the Ohio River and are less than $0.25 \mathrm{mi}$ apart. Both well fields combined form a series of wells paralleling the Ohio River over a distance of less than $1 \mathrm{mi}$. The Moundsville/Glendale model is simplistic from a hydrogeologic standpoint, and is based on simple geometric cross sections representing aquifer geometry with little variation of hydraulic data within the model. The actual geometry and hydraulic characteristics of the aquifer are likely much more complicated.

Data used in the design and calibration of the Moundsville/ Glendale model included written records from archives of the Moundsville (James Woods, Moundsville Water Department, written commun., 2002) and Glendale (Joe Blair, Glendale Water Department, written commun, 2002) Water Plants. Wellhead protection plans prepared by the West Virginia Rural Water Association also provided significant data and insight to conceptualize flow processes in the aquifer for the Moundsville (West Virginia Rural Water Association, 1999a) and Glendale (West Virginia Rural Water Association, 1999b) well fields. In addition, USGS personnel measured water levels in eight nonpumping wells in the Moundsville/Glendale area to assist in model calibration.

\section{Boundary Conditions and Layers}

Due to the limited amount of data and the small size of the study area, the Moundsville/ Glendale model is very simple. It consists of only two layers, a lower layer extending from an elevation of 575 to $605 \mathrm{ft}$ representing the lower sand and gravel alluvial aquifer and an upper layer extending from $605 \mathrm{ft}$ to land surface representing an upper silt and clay confining layer. The model consists of 52 rows and 31 columns and contains 1,612 cells (fig. 18). Approximately 40 percent of the cells represent areas with bedrock outcrops and are inactive. The model encompasses an area of $7,766 \mathrm{ft}$ by $15,276 \mathrm{ft}$, or approximately $4.25 \mathrm{mi}^{2}$.

As with the other models, the major boundary conditions for the model are river cells and inactive cells. River cells only were applied to the Ohio River; no tributary streams were simulated in the Glendale/Moundsville area. During the course of this investigation, no flow was evident in any tributary streams in the model area. Unfortunately, the Moundsville/Glendale area was experiencing a severe drought at the time field data were collected for this study; however, even if flow had been present, data collected for the Point Pleasant and Parkersburg/ Vienna models indicate a lack of interaction between tributary streams to the Ohio River and the underlying alluvial aquifer. As with the other models, the seepage of water from adjacent bedrock areas was considered minimal in comparison to flow in the alluvium and infiltration of water from the Ohio River. Therefore, the bedrock areas in the model area were designated as inactive cells.

Hydraulic conductivity data were sparse. A value of $500 \mathrm{ft} / \mathrm{d}$ was assigned to the alluvial sand and gravel layer, and a value of $1 \mathrm{ft} / \mathrm{d}$ was assigned to the overlying silt and clay confining unit. Estimates of hydraulic conductivity were taken from a statewide report on aquifer characteristics, and data from Marshall County were used to assign values of hydraulic conductivity to the modeled area (Kozar and Mathes, 2001).

Recharge was uniformly applied to the model at a rate of $11 \mathrm{in} / \mathrm{yr}$. This rate is similar to that used in the other models. The relatively thin overlying silt and clay unit and the high permeability of the underlying aquifer results in a slightly higher recharge than in areas dominated by thick silt and clay confining units.

\section{Model Calibration and Limitations}

Data available for design and calibration of a groundwater-flow model for the Moundsville/ Glendale area are minimal. Nevertheless, due to the small size of the study area, the water levels that were measured, and the knowledge gained in the design and calibration of the three previous models, groundwater flow in the Moundsville/Glendale area was simulated. The ground-water-flow model for the Moundsville/Glendale area was calibrated by matching simulated and measured water levels. A total of only 8 wells provided water-level data for model calibration. The area is almost exclusively served by public water systems and the 8 wells measured were the only wells available in the study area. Funds were not available for drilling monitoring wells as a part of this investigation and the simulation for the Moundsville/Glendale area was scheduled by design to represent a more or less worst case data scenario for modeling activities in Ohio River alluvium. Due to these limitations, model calibration goals were to match simulated to observed heads within $20 \%$ of the overall range in water level within the aquifer (about + or - 2.4 feet). Of the 8 wells used for model calibration, only one had a water level which did not meet the $2.4 \mathrm{ft}$ error criteria. The calibrated model had a mean error of just $-0.51 \mathrm{ft}$ and a root mean-squared error of $2.10 \mathrm{ft}$.

Major limitations of the accuracy of the Moundsville/ Glendale model are primarily related to a lack of data. Additional data including water levels, borehole logs, and aquifertest data would be needed to better refine the model. Any interpretation of ground-water flow on the basis of this model should be viewed as preliminary and subject to revision given additional data.

\section{Model Analysis and Interpretation}

Four principal pumping centers were simulated for the Moundsville/Glendale area. These include the Moundsville and Glendale well fields, an extraction well for ground-water remediation at a local gas station, and the hospital in Glendale. The major pumping center is the Moundsville well field. Pumping from the Moundsville well field produces a large cone of depression around the well field and throughout the surrounding alluvium (fig. 19). Of the approximately $2.0 \mathrm{Mgal} / \mathrm{d}$ of water pumped from the Moundsville well field, approximately 


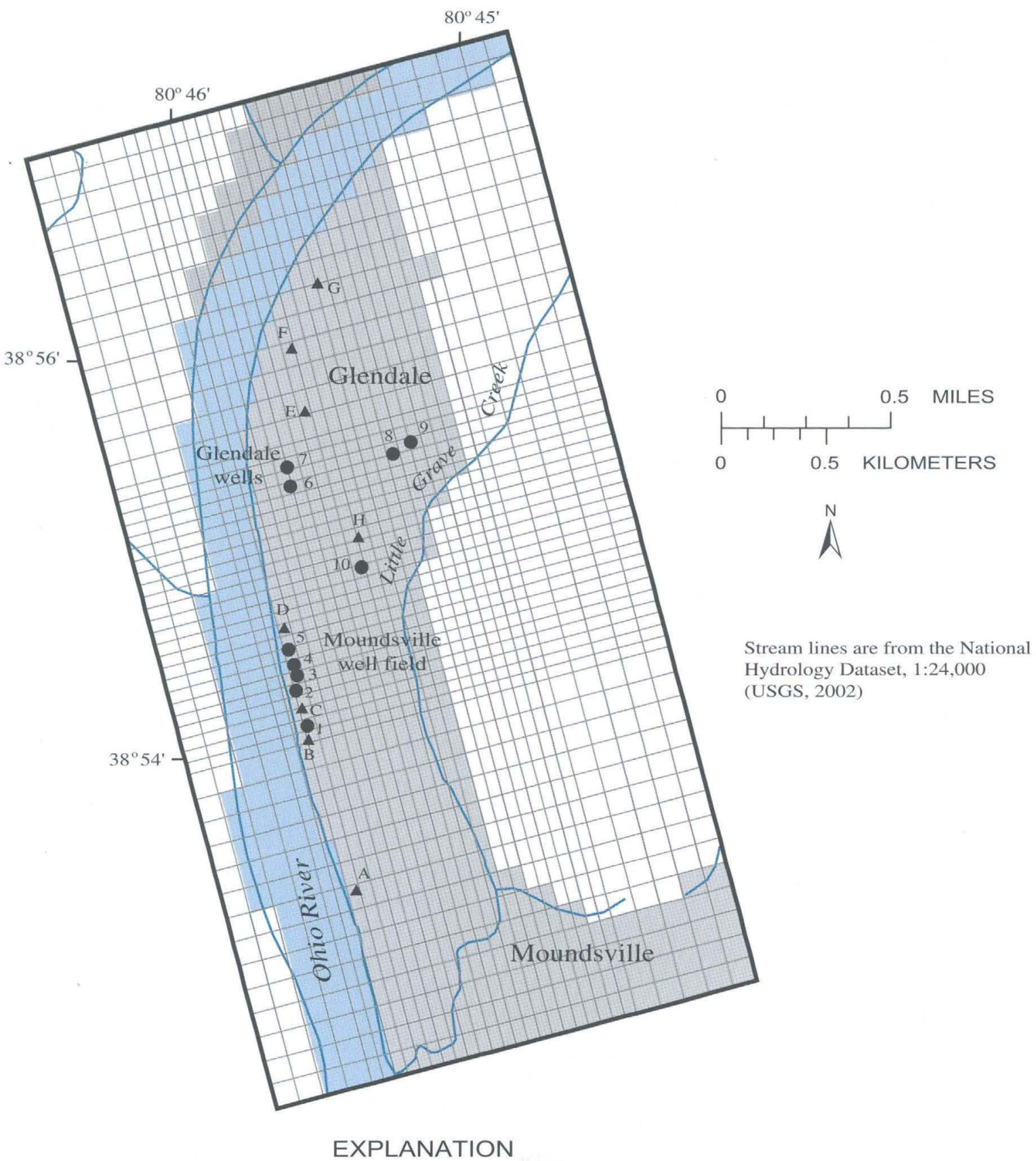

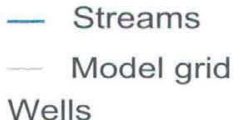

Wells

A Head observation

- Production
Model boundary

Model cell assignment

$\square \quad$ River
$\square \quad$ Active
$\square \quad$ Inactive

Figure 18. Model grid, locations of production and head observation wells, and inactive cells for the Moundsville/Glendale model. 


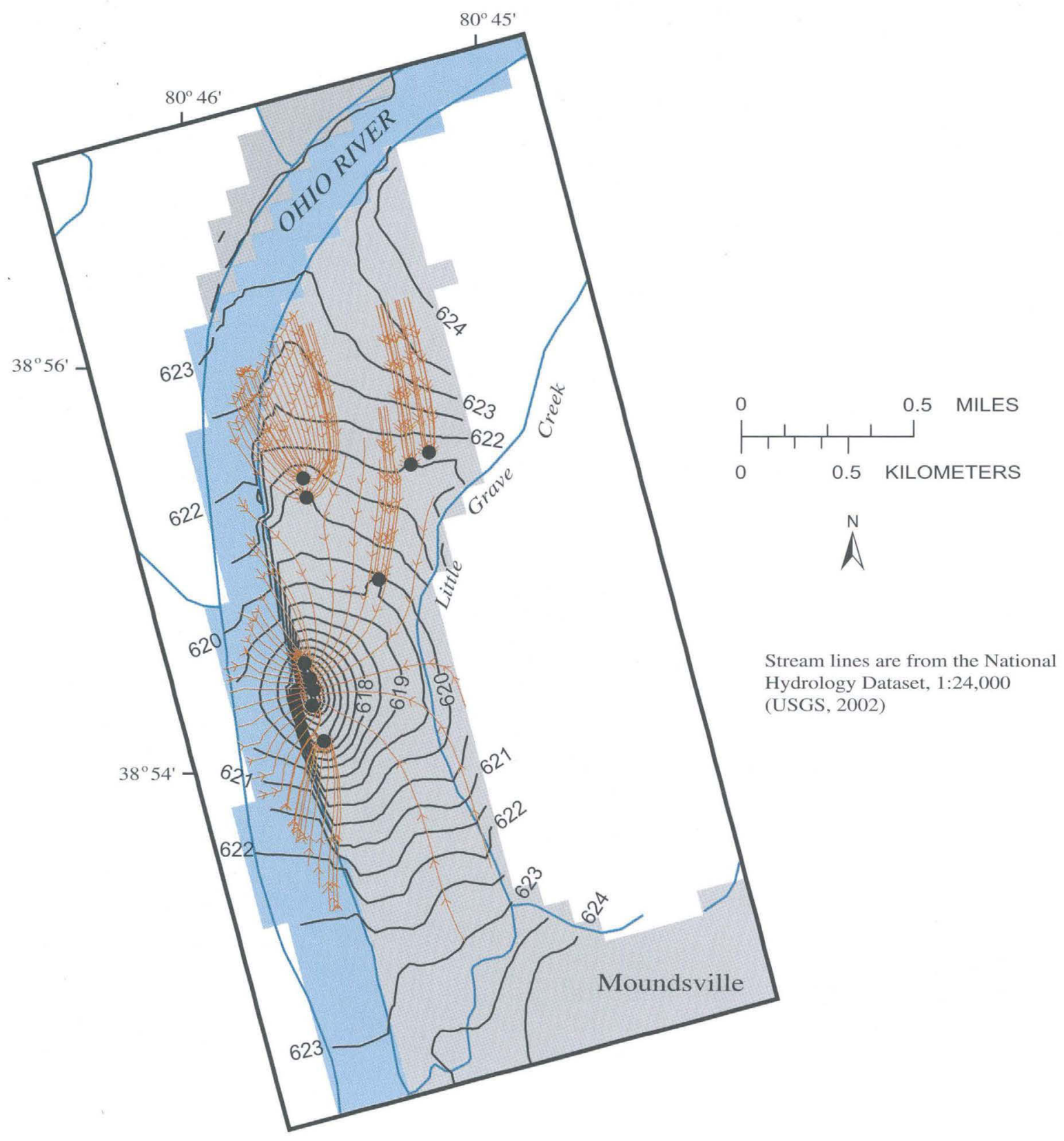

EXPLANATION

- 5-year time-of-travel paths (each arrow represents 1 year)

- Equipotential isolines

- Streams

- Production wells
Model boundary Model node assignment

$\square$ River Active Inactive

Figure 19. Calibrated heads and 5-year time-of-travel paths to the Moundsville and Glendale well fields in the lower layer of the model. 
half is derived from induced infiltration directly from the Ohio River. The remainder is derived from capturing ground water that would have flowed to the Ohio River from alluvium to the north, east, and south of the well field. The 5-year time-of-travel area estimated for the well field covers an elliptical area of approximately $6,750 \mathrm{ft}$ by $3,250 \mathrm{ft}$, or approximately $0.79 \mathrm{mi}^{2}$.

The second major pumping center is the Glendale well field. The majority of water flowing ( 72 percent) to the Glendale well field is induced infiltration of water from the Ohio River. A smaller percentage of flow (28 percent) is derived by capturing water from the alluvial terraces north of the well field. The 5-year time-of-travel area is small, approximately $2,750 \mathrm{ft}$ by $1,150 \mathrm{ft}$, or $0.11 \mathrm{mi}^{2}$ (fig. 19). Two other minor pumping centers, a local gas station and a hospital, receive 100 percent of flow from the alluvium with no induced infiltration from the Ohio River. The primary recharge area for these two minor withdrawals is primarily to the north of the wells.

\section{Sensitivity Analysis}

Ground-water-flow models described in this report were designed and calibrated based on various parameters: boundary conditions, recharge, layer configurations, and hydraulic conductivity. Because boundary conditions and layer configurations were established from site-specific data and well logs, there was little opportunity to vary these parameters. Only recharge and hydraulic conductivity values could be varied in each model for calibration purposes. Sufficient data were available to develop good preliminary estimates of hydraulic conductivity and recharge. Significant variability in recharge and hydraulic conductivity resulted from variations in the composition of the alluvial sediments in each modeled area. This was especially true for the upper silt and clay confining layers for which little data were available. As a result, parameters were varied during the calibration phase to provide a best fit between observed and calculated hydraulic heads and hydrologic budgets. Parameters were also varied to determine how "sensitive" the models were to variations in input parameters.

The ranges of hydraulic conductivity and recharge rates for the various models and the effect varying these parameters had on the calibration error for the models (root mean squared and mean error) are listed in table 4 . The effects of varying the parameters arepronounced in some instances and negligible in others. Overall, the models are more sensitive to variations in recharge than they are to variations in hydraulic conductivity. The models also are sensitive to the hydraulic conductivity of confining units when hydraulic conductivities are small. An example is the Washington Bottom and Moundsville upper terraces (table 4) where small changes in hydraulic conductivity have rather pronounced effects on simulated heads. As a result, known values of hydraulic conductivity were used to calibrate the models where possible. The major data limitation indicated by sensitivity analysis is information on hydraulic properties of the confining units.

Table 4. Effects of varying parameters for sensitivity analysis during model development and calibration.

[ft, feet; $\mathrm{ft} / \mathrm{d}$, feet per day; in/yr, inches per year; numbers in bold type indicate the parameters varied during the sensitivity analysis].

\begin{tabular}{|c|c|c|c|c|c|c|c|c|}
\hline \multirow[b]{2}{*}{$\begin{array}{c}\text { Description of model } \\
\text { areas }\end{array}$} & \multicolumn{4}{|c|}{ Calibrated Model } & \multicolumn{4}{|c|}{ Sensitivity Tests } \\
\hline & $\begin{array}{c}\text { Hydraulic } \\
\text { conductivity } \\
(\mathrm{ft} / \mathrm{d})\end{array}$ & $\begin{array}{l}\text { Recharge } \\
\text { (in/yr) }\end{array}$ & $\begin{array}{c}\text { Mean } \\
\text { error } \\
(\mathrm{ft})\end{array}$ & $\begin{array}{l}\text { Root mean } \\
\text { squared } \\
\text { error }\end{array}$ & $\begin{array}{l}\text { Hydraulic } \\
\text { conductivity } \\
\text { (ft/d) }\end{array}$ & $\begin{array}{l}\text { Recharge } \\
\text { (in/yr) }\end{array}$ & $\begin{array}{c}\text { Mean } \\
\text { error } \\
\text { (ft) }\end{array}$ & $\begin{array}{c}\text { Root mean } \\
\text { squared } \\
\text { error }\end{array}$ \\
\hline \multicolumn{9}{|c|}{ Point Pleasant Area } \\
\hline Point Pleasant Oxbow & 87 & 11.0 & & & 87 & 9.0 & -1.80 & 4.05 \\
\hline $\begin{array}{l}\text { Camp Conley } \\
\text { Well Field }\end{array}$ & 83 & 12.0 & & & 43 & 12.0 & 0.60 & 3.47 \\
\hline Lubeck Wellfield & 190 & 7.0 & 1.59 & 3.24 & 300 & 7.0 & 2.83 & 4.60 \\
\hline $\begin{array}{l}\text { Washington Bottom } \\
\text { Wellfields }\end{array}$ & 190 & 7.0 & & & 190 & 12.0 & 1.96 & 4.81 \\
\hline $\begin{array}{l}\text { Washington Bottom } \\
\text { Upper Terraces }\end{array}$ & 1.0 & 9.8 & & & 0.5 & 9.8 & 0.93 & 4.29 \\
\hline
\end{tabular}




\section{Ground-Water Flow in Selected Ohio River Alluvial Aquifers, West Virginia}

Table 4. Effects of varying parameters for sensitivity analysis during model development and calibration.-Continued

[ft, feet; ft/d, feet per day; in/yr, inches per year; numbers in bold type indicate the parameters varied during the sensitivity analysis].

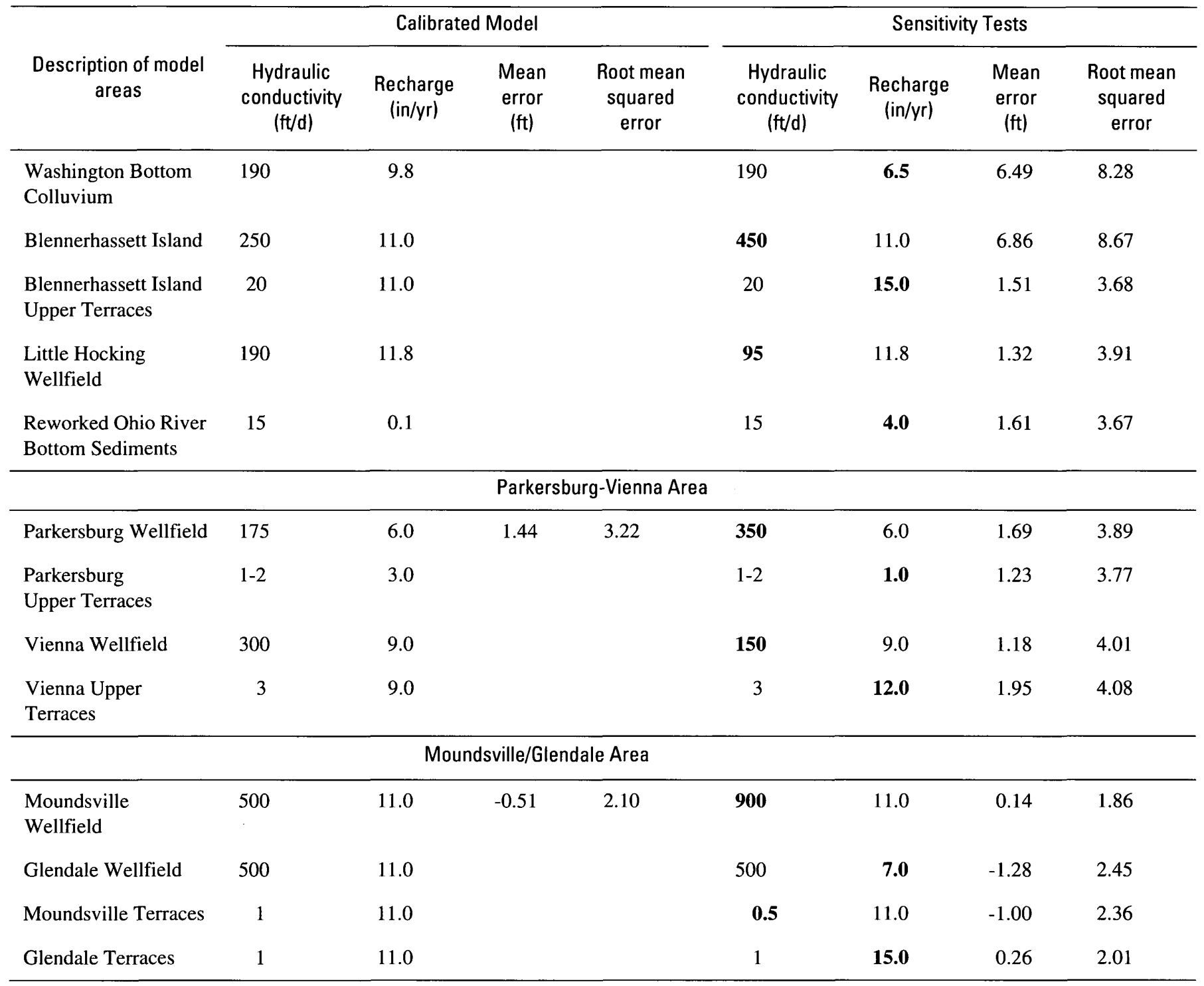

\section{Summary}

Ground-water-flow simulations were developed for alluvial aquifers bordering the Ohio River in Point Pleasant, Lubeck/Washington Bottom, Parkersburg/Vienna, and Moundsville/Glendale, West Virginia. The models were developed to assess ground-water-flow rates and directions in alluvial aquifers and to assess the effects of large ground-water withdrawals on the ground-water flow system. This study was initiated in 2000 and was done in cooperation with the West Virginia Bureau for Public Health (WVBPH). The models can be used by water-resources managers to develop source-water protection areas for public supply wells in the study areas and in other Ohio River alluvial aquifers. Five-year time-of-travel zones, identified by use of particle tracking, were included as part of this investigation.

The geology of the areas for which ground-water models were prepared is typified by highly permeable sand and gravel glacial outwash deposits overlying bedrock. The hilly terrain of south-southeast dipping Lower Permian and Pennsylvanian age rocks is dominant in the upland areas and gives way to a flood plain less than 500 feet $(\mathrm{ft})$ below. Pleistocene alluvium from glacial outwash deposits of the pre-, early-, and late-Wisconsinan age has been reworked and deposited at lower elevations, forming terraces. The alluvial deposits have the capacity to yield millions of gallons of water per day to wells, especially wells completed in river-bank deposits or completed as long horizontal lateral collector wells extending beneath the river. Fluvially deposited layers of silt and clay typically cover the 
glacial outwash deposits, forming a thin overlying confining unit that limits recharge from precipitation. The confining unit is present in all modeled areas but is partially absent in the Point Pleasant area. The alluvium there, from the river bank to about $1 \mathrm{mile}(\mathrm{mi})$ east of the river is typified by more permeable sands and to a lesser extent gravels at the base. An old meander cutoff (oxbow) in the Point Pleasant area is characterized by a confining layer of silt and clay between upper and lower alluvial aquifers.

Under base-flow conditions, hydraulic gradients typically indicate ground-water flow from the alluvium towards the river. Infiltration from the river can occur naturally when local hydraulic gradients are reversed during high river stages that are common during floods. Induced infiltration from the Ohio River is likely where the aquifer is pumped close to the river, although local heterogeneity of river bottom sediments may reduce the connection (Mathes and others, 1995; Jeffords, 1945).

No appreciable gains or losses in streamflow were detected in any of the areas and tributary streams are therefore believed to have little connection with the underlying alluvial aquifer. Discharge from surrounding bedrock aquifers serves as an additional source of ground water but is likely small in comparison to that derived from precipitation. In the absence of significant recharge from tributary streams and from bedrock, the majority of recharge under ambient conditions is from precipitation. A large part of precipitation is lost to surface runoff and evapotranspiration. Estimates of ground-water recharge for alluvial aquifers bordering the Ohio River range from 3 to $20 \mathrm{in} /$ yr. Estimates of ground-water recharge applied to models in this report range from 3 to 12 (in/yr) and vary based on the composition of the alluvium. Alluvial deposits with a high percentage of sand and gravel tend to have recharge rates approaching 12 in/yr whereas the deposits with a high percentage of silt and clay (thicker and more areally extensive confining units) may have recharge rates as low as $3 \mathrm{in} / \mathrm{yr}$.

In the study area, the alluvium varied in thickness from 45 to $100 \mathrm{ft}$. The thickness in the Point Pleasant well field was (75-95 ft), Lubeck (60-85 ft), Parkersburg (45-65 ft), Vienna (70 to $80 \mathrm{ft}$ ), and Moundsville/Glendale (65 to $100 \mathrm{ft}$ ). The average hydraulic conductivity of the alluvium in each well field was Point Pleasant (350 ft/d)), Lubeck (190 ft/d), Parkersburg $(175 \mathrm{ft} / \mathrm{d})$, Vienna (300 ft/d), Moundsville (500 ft/d), and Glendale $(500 \mathrm{ft} / \mathrm{d})$. The depth to water in the alluvium varied from 24 to $58 \mathrm{ft}$ below land surface.

Because glacial outwash deposits in alluvial flats in the northern part of the study area consist of coarser grained sediments than the alluvial flats further to the south, the hydraulic conductivity of the alluvial flats to the north (300 to $500 \mathrm{ft} / \mathrm{d}$ ) are typically higher than those to the south ( 75 to $300 \mathrm{ft} / \mathrm{d}$ ). Finegrained flood plain sediments of fluvially deposited silt and clay cover the coarser grained glacial outwash deposits but typically have very low hydraulic conductivities of 0.1 to $3.0 \mathrm{ft} / \mathrm{d}$.

Public-supply wells in alluvial sediments along the Ohio River have the capacity to yield extremely large quantities of water. For public supplies described in this report, Parkersburg withdraws the most water at 4.78 million gallons per day (Mgal/ d) and the Camp Conley Public Service District withdraws the least at only 34,000 gallons per day (gal/d). Average groundwater withdrawals for the remaining well fields are: Point Pleasant (1.09 Mgal/d), Lubeck

(0.67 Mgal/d), Vienna (1.40 Mgal/d), Moundsville (2.36 Mgal/ d), and Glendale $(0.26 \mathrm{Mgal} / \mathrm{d})$. Two large chemical manufacturing facilities in the area immediately north of the Lubeck well field withdraw approximately $8.80 \mathrm{Mgal} / \mathrm{d}$ and $2.06 \mathrm{Mgal} / \mathrm{d}$, respectively. Such large withdrawals are common for industrial and public-supply wells along the Ohio River.

Results of the simulations conducted for the Point Pleasant area indicate that only a minimal amount of the water (approximately 4 percent) that is pumped from the Point Pleasant well field is derived from induced infiltration from the Ohio River. The majority of water ( 96 percent) is derived from a large capture zone, approximately $5,000 \mathrm{ft}$ by $4,700 \mathrm{ft}$, that surrounds the Point Pleasant well field. The 5-year time-of-travel area occupies approximately $0.84 \mathrm{mi}^{2}$. The contaminated land to the south of the plant is within the cone of depression of the nearby Point Pleasant well field. Water from the adjacent contaminated site could potentially migrate to the Point Pleasant well field, depending on pumping scenarios in the well field. For the Camp Conley Public Service District, none of the water pumped originates from the Ohio River. The 5-year time-of-travel area for the Camp Conley well field is small, less than $0.25 \mathrm{mi}$ long, and derives most of its water from a small area primarily to the east of the well field. It is not likely to be affected by the contaminated sites adjacent to the Point Pleasant well field but could be vulnerable to contamination from other potential sources of contaminants in the area.

In the Lubeck well field, ground-water flow simulations show that ground water is derived from the area immediately adjacent to the well field near Vaughts Run and Sandy Creek. Part of the flow also is derived directly from the Ohio River. Hydraulic gradients indicate that the water table near the Lubeck well field is actually at a higher elevation than the water table near the chemical manufacturing facilities in the Washington Bottom area. It does not appear likely that the Lubeck well field captures flow from the northern part of the Washington Bottom area. Of the approximately 665,000 gal of water pumped daily from the Lubeck well field, approximately $261,600 \mathrm{gal}$ (39 percent) is derived from induced infiltration from the Ohio River and approximately 403,400 gal (61 percent) is derived from ground water in the alluvium that would otherwise have flowed to the Ohio River.

Ground-water flow in the alluvial aquifer near Parkersburg and Vienna is complicated and has been modified substantially by the cones of depressions formed from the major groundwater withdrawals in the area. This is especially true for the Parkersburg well field where pumping of $4.78 \mathrm{Mgal} / \mathrm{d}$ has resulted in a cone of depression approximately $2 \mathrm{mi}$ long parallel to the Ohio River and approximately $1 \mathrm{mi}$ wide. Conversely, cones of depression around wells in the Vienna area are much smaller. This is due to a difference in total withdrawals and in well spacing. Wells in the Vienna area, including the municipal 
wells and wells at an industrial plant and nearby golf course, withdraw a total of $1.58 \mathrm{Mgal} / \mathrm{d}$ compared to $4.78 \mathrm{Mgal} / \mathrm{d}$ for the Parkersburg plant. The wells in the Vienna area are scattered over the entire alluvial flat from the southern end of Vienna to its northern terminus, whereas wells in the Parkersburg well field are clustered in a tight group on the river bank and on Neal Island. In addition, the deposits in the Parkersburg area have a higher percentage of silt and clay than do alluvial deposits in the Vienna area, and the confining unit in Parkersburg is substantially thicker than the confining unit in the Vienna area. As a result, withdrawal of ground water in the Parkersburg area produces larger cones of depression than would occur in the coarser grained deposits in the Vienna area. Approximately 75 percent of the water pumped from the Parkersburg well field is derived from infiltration of water from the Ohio River whereas only 7 percent of water pumped from the Vienna well field is derived from the Ohio River.

In the Moundsville/Glendale area, pumping from the Moundsville well field produces a large cone of depression around the well field and throughout the alluvium. Of the approximately $2.0 \mathrm{Mgal} / \mathrm{d}$ pumped from the Moundsville well field, approximately half is direct infiltration of water from the Ohio River. The remainder is derived from capturing ground water in the alluvium that would have flowed to the Ohio River from the area south of the well field. The majority of recharge (72 percent) to the Glendale well field is direct infiltration of water from the Ohio River. A smaller proportion ( 28 percent) of recharge is derived from precipitation falling on the alluvium. Pumping from the Glendale well field does not produce a cone of depression but rather a small 5-year time-of-travel area of approximately $0.11 \mathrm{mi}^{2}$.

\section{References Cited}

Burgess and Niple, Limited, 1988, Final report water supply well drilling and test pumping conducted on Blennerhassett Island: June 1988, 34 p.

Burgess and Niple, Limited, 1996, Little Hocking Water Association, Inc., Wellhead Protection Plan-Phase 1, Determination of Wellhead Protection areas and potential pollution source inventory: November 1996, [variously paged].

Carlston, C.W., and Graeff, G.D., Jr., 1956, Ground-water resources of the Ohio River Valley in West Virginia, pt. III of Geology and Economic Resources of the Ohio River Valley in West Virginia: West Virginia Geological Survey v. 22, p. 1-131.

CDM, Federal Programs Corporation, 2002a, Draft report of advective movement and travel times of contaminants at the Vienna PCE Superfund site, Vienna, West Virginia: July 2002, [variously paged].

CDM, Federal Programs Corporation, 2002b, Final report of advective movement and travel times of contaminants at the Vienna PCE Superfund site, Vienna, West Virginia: July 2002, [variously paged].
Corporate Remediation Group, 2003, Revised groundwater flow model, Dupont Washington Works, Washington, West Virginia: January 2003, 27 p.

Corporate Remediation Group, 1999, RCRA Facility Investigation Report Dupont Washington Works, Washington, West Virginia: RCRA facility investigation report, [variously paged].

Cox, James M., 1998, Wellhead protection survey, Lubeck PSD: May 1998.

Cross, A.T., and Schemel, M.P., 1956, Geology of the Ohio River valley in West Virginia, pt. I of Geology and economic resources of the Ohio River valley in West Virginia, 1956: West Virginia Geological and Economic Survey v. 22, p. 1-149.

Deutsch, Morris, Dove, G.D., Jordan, P.R., and Wallace, J.C., 1966, Ground-water distribution and potential in the Ohio River basin, in Ohio River basin comprehensive survey, v. 6, Appendix E, ground water: Cincinnati, Ohio, The Army Corps of Engineers, U.S. Army Engineer Division, Ohio River, 197 p., 32 plates.

Freeze and Cherry, 1979, Groundwater: Englewood Cliffs, N.J., Prentice-Hall, Inc. 604 p.

Gallaher, J.T., and Price, W.E., Jr., 1966, Hydrology of the alluvial deposits in the Ohio River Valley in Kentucky: U.S. Geological Water Supply Paper 1818, 80 p.

Grimsley, G.P., 1910, [Detailed geologic report of] Pleasants, Wood, and Ritchie Counties, West Virginia: West Virginia Geological Survey County Report, 352 p., 21 plates.

Groundwater Services, Inc., 1999, RCRA Facility Investigation for Shell Chemical Company, Belpre, Ohio: December 1999, [variously paged].

Grubb, H.F., 1975, Simulated drawdown for selected well fields in the Ohio River alluvial aquifer: U.S. Geological WaterResources Investigations Report 74-002, 45 p

Hall, W.M., 1917, The water supply of Parkersburg, West Virginia: American Society of Civil Engineers Transactions, v. 81, p. 749-787.

Harbaugh, A.W., Banta, E.R., Hill, M.C., and McDonald, M.G., 2000, MODFLOW-2000, The U.S. Geological Survey modular ground-water model-User guide to modularization concepts and the ground-water flow process: U.S. Geological Survey Open-File Report 00-92, 121 p.

Harbaugh, Arlen W. (U. S. Geological Survey, Reston, VA, United States), McDonald, Michael G., 1996, User's documentation for MODFLOW-96, an update to the U.S. Geological Survey modular finite-difference ground-water flow model, U.S. Geological Survey Open File Report 96-0485, p. 56, 7 refs. (NC, Da, M, Wb.).

Hennen, R.V., 1909, [Detailed geologic report of] Marshall, Wetzel, and Tyler Counties, West Virginia: West Virginia Geological Survey County Report, 654 p., 12 plates.

IT Corporation, 1996, Site Wide Hydrogeological Study West Virginia Ordnance Works, Mason County, West Virginia: [variously paged]. 
Jeffords, R.M., 1945, Ground-water conditions along the Ohio Valley at Parkersburg, West Virginia: West Virginia Geological Survey Bulletin No. 10, 57 p.

Kazmann, R.G., Jeffords, R.M., and Schaefer, E.J., 1943, Water supply of the West Virginia Ordinance Works, Pt. Pleasant, West Virginia: U.S. Geological Survey Open-File Report, [variously paged].

Kernodle, J.M., 1977, Theoretical drawdown due to simulated pumpage from the Ohio River alluvial aquifer near Siloam, Kentucky: U.S. Geological Water-Resources Investigations Report 77-0024, $39 \mathrm{p}$

Kozar, M.D., and Mathes, M.V., 2001, Aquifer-characteristics data for West Virginia: U.S. Geological Water-Resources Investigations Report 01-4036, 74 p.

Krebs, C.E., 1911, [Detailed geologic report of] Jackson, Mason, and Putnam Counties, West Virginia: West Virginia Geological Survey County Report, 387 p., 31 plates.

Leake, S.A., and Claar, D.V., 1999, Procedures and computer programs for telescopic mesh refinement using MODFLOW: U.S. Geological Survey Open-File Report 99-238, 53 p.

Leggette, Brashears, and Graham, Inc., 1986, Hydrogeologic evaluation for additional water supply from Blennerhassett Island: May 1986, $18 \mathrm{p}$.

Lyverse, M.A., Starn, J.J., and Unthank, M.D., Hydrogeology and simulation of ground-water flow in the alluvial aquifer at Louisville, Kentucky: U.S. Geological Water-Resources Investigations Report 91-4035, 41 p.

Mathes, M.V., Shultz, R.A., and Bader, J.S., 1995, Groundwater hydrology of the area bordering the Ohio River between Kenova and Waverly, West Virginia: U.S. Geological Survey Open-File Report 95-711, 46 p.

McDonald, M.G., and Harbaugh, A.W., 1988, A modular three dimensional finite-difference ground-water flow model:U.S. Geological Survey Techniques of Water Resources Investigations of the United States Geological Survey book 6, chap. A 1, $586 \mathrm{p}$.

National Oceanic and Atmospheric Administration, 2002, Monthly Station Normals of Temperature, Precipitation, and Heating and Cooling Degree Days 1971-2000: U.S. Department of Commerce - National Oceanic and Atmospheric Administration Climatography of the United States No. 81 part 46 for West Virginia, $23 \mathrm{p}$.

P.E. LaMoureaux and Associates, Inc, 1978, Hydrogeologic evaluation of water-supply alternatives in the vicinity of Point Pleasant, West Virginia: October 1978, [variously paged].

Ranney Corporation, 1981, Maintenance report-Ranney Collector, Weirton, West Virginia, $40 \mathrm{p}$.

Reilly, T.E., 2001, System and boundary conceptualization in ground-water flow simulation: Techniques of WaterResources Investigations of the U.S. Geological Survey, book 3, chap. B8, $30 \mathrm{p}$.

Rorabaugh, M.I., 1949, Progress report on the ground-water resources of the Louisville area, Kentucky, 1945-49: City of Louisville and Jefferson County, Ky., 64 p.
Simard, C.M., 1989, Geologic history of the lower terraces and floodplains of the Upper Ohio River Valley: West Virginia Geological and Economic Survey Open-File Report 8903, $160 \mathrm{p}$.

Unthank, M.D., 1996, Geohydrology and simulation of groundwater flow for the Ohio River alluvial aquifer near Owensboro, northwestern Kentucky: U.S. Geological Survey Water-Resources Investigations Report 96-4274, 29 p.

Unthank, M.D., 1998, Geohydrology and simulation of groundwater flow for the Ohio River alluvial aquifer near Carrollton, Kentucky: U.S. Geological Survey Water-Resources Investigations Report 98-4215, 48 p.

Unthank, M.D., and Nelson, H.L., Jr., 1999, Hydrogeology and simulation of ground-water flow in the Ohio River alluvial aquifer near West Point, Kentucky: U.S. Geological Survey Water-Resources Investigations Report 99-4265, 56 p.

U.S. Environmental Protection Agency, 2004, Text and description of the 1974 Safe Drinking Water Act and the 1996 amendments to the Safe Drinking Water Act: accessed June 6, 2004 at URL http://www.epa.gov/safewater/sdwa/ sdwa.html\#theact

Waterloo Hydrogeologic, 2000, Visual MODFLOW Users Manual: Waterloo, Ontario, Canada, Waterloo Hydrogeologic Inc., $311 \mathrm{p}$.

Winston, R.B., 1999, Upgrade to MODFLOW-GUI; addition of MODPATH, ZONEBDGT, and additional MODFLOW packages to the U.S. Geological Survey MODFLOW-96 Graphical-User Interface: U.S. Geological Survey Open-File Report 99-184, 72 p.

West Virginia Rural Water Association, 1999a, Moundsville, West Virginia Wellhead Protection Plan: West Virginia Rural Water Association report, $60 \mathrm{p}$.

West Virginia Rural Water Association, 1999b, Glendale, West Virginia Wellhead Protection Plan: West Virginia Rural Water Association report, $69 \mathrm{p}$. 
Mark D. Kozar and Kurt J. McCoy - Geohydrology and Simulation of Ground-Water Flow in Selected Ohio River Alluvial Aquifers, West Virginia Scientific Investigations Report 2004-5088 